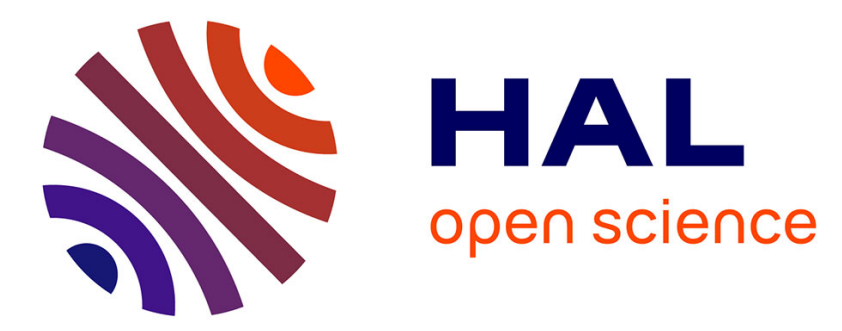

\title{
Global satellite observations of column-averaged carbon dioxide and methane: The GHG-CCI XCO2 and XCH4 CRDP3 data set
}

\author{
M. Buchwitz, M. Reuter, O. Schneising, W. Hewson, R.G. Detmers, H. \\ Boesch, O.P. Hasekamp, I. Aben, H. Bovensmann, J.P. Burrows, et al.
}

\section{To cite this version:}

M. Buchwitz, M. Reuter, O. Schneising, W. Hewson, R.G. Detmers, et al.. Global satellite observations of column-averaged carbon dioxide and methane: The GHG-CCI XCO2 and XCH4 CRDP3 data set. Remote Sensing of Environment, 2017, 203, pp.276-295. 10.1016/J.RSE.2016.12.027 · hal-02951858

\section{HAL Id: hal-02951858 \\ https://hal.science/hal-02951858}

Submitted on 24 Jun 2021

HAL is a multi-disciplinary open access archive for the deposit and dissemination of scientific research documents, whether they are published or not. The documents may come from teaching and research institutions in France or abroad, or from public or private research centers.
L'archive ouverte pluridisciplinaire HAL, est destinée au dépôt et à la diffusion de documents scientifiques de niveau recherche, publiés ou non, émanant des établissements d'enseignement et de recherche français ou étrangers, des laboratoires publics ou privés. 


\section{Global satellite observations of column-averaged carbon dioxide and methane:} The GHG-CCI $\mathrm{XCO}_{2}$ and $\mathrm{XCH}_{4} \mathrm{CRDP3}$ data set

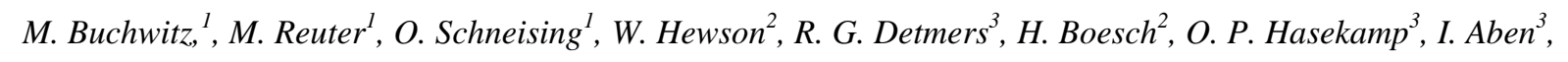

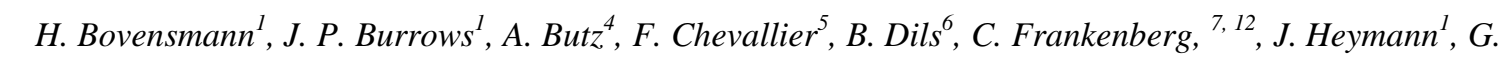

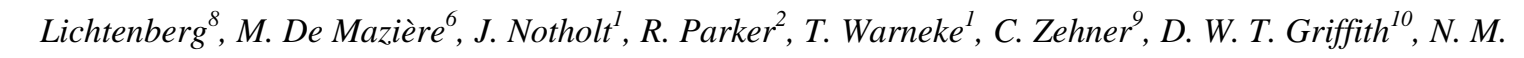

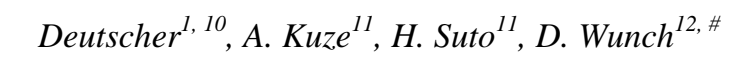

1. Institute of Environmental Physics (IUP), University of Bremen, Bremen, Germany.

2. University of Leicester, Leicester, United Kingdom.

3. SRON Netherlands Institute for Space Research, Utrecht, Netherlands.

4. Karlsruhe Institute of Technology (KIT), Karlsruhe, Germany.

5. Laboratoire des Sciences du Climat et de l'Environnement (LSCE), Gif-sur-Yvette, France.

6. Belgian Institute for Space Aeronomy (BIRA), Brussels, Belgium.

7. Jet Propulsion Laboratory (JPL), Pasadena, California, United States of America.

8. Deutsches Zentrum für Luft- und Raumfahrt (DLR), Oberpfaffenhofen, Germany.

9. European Space Agency (ESA), ESRIN, Frascati, Italy.

10. University of Wollongong, Wollongong, Australia.

11. Japan Aerospace Exploration Agency (JAXA), Tsukuba, Japan.

12. California Institute of Technology, Pasadena, California, United States of America.

\#) Now at: University of Toronto, School of the Environment, Toronto, Canada.

*) Corresponding author: Michael Buchwitz, Institute of Environmental Physics (IUP), University of Bremen, FB1, Otto Hahn Allee 1, 28334 Bremen, Germany, Phone: +49-(0)421-218-62086, Fax: +49-(0)421-218-62070, E-mail:Michael.Buchwitz@iup.physik.uni-bremen.de. 
Abstract

Carbon dioxide $\left(\mathrm{CO}_{2}\right)$ and methane $\left(\mathrm{CH}_{4}\right)$ are the two most important greenhouse gases emitted by mankind. Better knowledge of the surface sources and sinks of these Essential Climate Variables (ECVs) and related carbon uptake and release processes is needed for important climate change related applications such as improved climate modelling and prediction. Some satellites provide near-surfacesensitive atmospheric $\mathrm{CO}_{2}$ and $\mathrm{CH}_{4}$ observations that can be used to obtain information on $\mathrm{CO}_{2}$ and $\mathrm{CH}_{4}$ surface fluxes. The goal of the GHG-CCI project of the European Space Agency's (ESA) Climate Change Initiative $(\mathrm{CCI})$ is to use satellite data to generate atmospheric $\mathrm{CO}_{2}$ and $\mathrm{CH}_{4}$ data products meeting demanding GCOS (Global Climate Observing System) greenhouse gas (GHG) ECV requirements. To achieve this, retrieval algorithms are regularly being improved followed by annual data reprocessing and analysis cycles to generate better products in terms of extended time series and continuously improved data quality. Here we present an overview about the latest GHG-CCI data set called Climate Research Data Package No. 3 (CRDP3) focusing on the GHG-CCI core data products, which are column-averaged dry-air mole fractions of $\mathrm{CO}_{2}$ and $\mathrm{CH}_{4}$, i.e., $\mathrm{XCO}_{2}$ and $\mathrm{XCH}_{4}$, as retrieved from SCIAMACHY/ENVISAT and TANSO/GOSAT satellite radiances covering the time period end of 2002 to end of 2014. We present global maps and time series including initial validation results obtained by comparisons with Total Carbon Column Observing Network (TCCON) ground-based observations. We show that the GCOS requirements for systematic error $\left(<1 \mathrm{ppm}\right.$ for $\mathrm{XCO}_{2},<10 \mathrm{ppb}$ for $\left.\mathrm{XCH}_{4}\right)$ and long-term stability $\left(<0.2 \mathrm{ppm} /\right.$ year for $\mathrm{XCO}_{2},<2 \mathrm{ppb} /$ year for $\left.\mathrm{XCH}_{4}\right)$ are met for nearly all products (an exception is SCIAMACHY methane especially since 2010). For $\mathrm{XCO}_{2}$ we present comparisons with global models using the output of two $\mathrm{CO}_{2}$ assimilation systems (MACC version 14r2 and CarbonTracker version CT2013B). We show that overall there is reasonable consistency and agreement between all data sets (within 1-2 ppm) but we also found significant differences depending on region and time period. 


\section{Introduction}

Carbon dioxide $\left(\mathrm{CO}_{2}\right)$ is the most important human-emitted greenhouse gas responsible for global warming (IPCC, 2013). Despite its importance, our knowledge of the $\mathrm{CO}_{2}$ sources and sinks has significant gaps and does not meet all needs for attribution, mitigation and the accurate prediction of future climate change (e.g., Stephens et al., 2007; Canadell et al., 2010; IPCC, 2013; Ciais et al., 2014). Despite efforts to reduce $\mathrm{CO}_{2}$ emissions, atmospheric $\mathrm{CO}_{2}$ continues to increase with currently approximately 2 ppm/year (e.g., Fig. 1 (satellite-derived column-averaged $\mathrm{CO}_{2}$ ) and Le Quéré et al., 2015, based on Dlugokencky and Tans, 2015, NOAA/ESRL (near) surface $\mathrm{CO}_{2}$ concentrations). The situation is similar for methane $\left(\mathrm{CH}_{4}\right.$; e.g., Dlugokencky et al., 2009; IPCC, 2013; Kirschke et al., 2013; Houweling et al., 2014; Alexe et al., 2015).

The goal of the GHG-CCI project (Buchwitz et al., 2015), which is one of several projects of ESA's Climate Change Initiative (CCI, Hollmann et al., 2013), is to generate global satellite-derived atmospheric $\mathrm{CO}_{2}$ and $\mathrm{CH}_{4}$ data sets with as high as possible new information content on regional $\mathrm{CO}_{2}$ and $\mathrm{CH}_{4}$ sources and sinks, i.e., surface fluxes, to be extracted, for example, via inverse modeling (e.g., Reuter et al., 2014a; Alexe et al., 2015). GHG-CCI generates data sets of the Essential Climate Variable (ECV) Greenhouse Gases (GHG) as required by the GCOS (Global Climate Observing System) defined as follows (GCOS, 2011): "Product Number A.8.1: Retrievals of greenhouse gases, such as $\mathrm{CO}_{2}$ and $\mathrm{CH}_{4}$, of sufficient quality to estimate regional sources and sinks". 
Currently multi-year radiance measurements from two satellite instruments are used in GHG-CCI to retrieve information on atmospheric $\mathrm{CO}_{2}$ and $\mathrm{CH}_{4}$ with high near-surface-sensitivity: SCIAMACHY on ENVISAT (2002 - April 2012) (Burrows et al., 1995; Bovensmann et al., 1999) and TANSO-FTS on-board GOSAT (launched in 2009) (Kuze et al., 2009, 2014). Both instruments perform (or have performed) nadir observations in the near-infrared/short-wave-infrared (NIR/SWIR) spectral region covering the relevant absorption bands of $\mathrm{CO}_{2}, \mathrm{CH}_{4}$ and molecular oxygen $\left(\mathrm{O}_{2}\right)$. The latter is used to obtain the "dry-air column" needed to compute GHG column-averaged dry-air mole fractions, i.e., $\mathrm{XCO}_{2}$ (in ppm) and $\mathrm{XCH}_{4}$ (in ppb) from the retrieved GHG vertical columns (e.g., Buchwitz et al., 2005) and/or to obtain information on atmospheric scatterers, e.g., on aerosols and thin cirrus clouds. These two instruments are the two main sensors used within GHG-CCI but in the future other sensors with similar radiance observations may be added, e.g., NASA's successfully launched OCO-2 mission for $\mathrm{XCO}_{2}$ (Crisp et al., 2004; Bösch et al., 2011; Zhang et al., 2016) and ESA's Sentinel-5-Precursor mission for $\mathrm{XCH}_{4}$ (Veefkind et al., 2012; Butz et al., 2012).

During recent years significant progress has been made towards achieving the demanding satellite $\mathrm{XCO}_{2}$ and $\mathrm{XCH}_{4}$ requirements. Prior to the GHG-CCI project initial $\mathrm{XCO}_{2}$ retrievals were available from SCIAMACHY (e.g., Buchwitz et al., 2005, 2007; Schneising et al., 2008, 2009) but only first preliminary GOSAT retrievals. Progress has been made in terms of improved data quality, time coverage and interpretation of satellite $\mathrm{XCO}_{2}$ data products (using GHG-CCI and other products generated in Japan (e.g., Yoshida et al., 2013, Oshchepkov et al., 2011, 2013) and in the USA (e.g., O'Dell et al., 2012; Crisp et al., 2012)) to enhance our knowledge on the various sources and sinks of these gases (e.g., Basu et al., 2013; Maksyutov et al., 2013; Saeki et al., 2013; Chevallier et al., 2014; Takagi et al., 2014; Reuter et al., 2014a, 2014b; Houweling et al., 2015; Alexe et al., 2015).

For example, focusing on hemispheric data and on carbon-climate feedbacks, Schneising et al., 2014a, used SCIAMACHY $\mathrm{XCO}_{2}$ retrievals to study aspects related to the terrestrial carbon sink by looking at co-variations of $\mathrm{XCO}_{2}$ growth rates and seasonal cycle amplitudes with near-surface temperature. They found $\mathrm{XCO}_{2}$ growth rate changes of $1.25+/-0.32 \mathrm{ppm} /$ year/K (approximately $2.7+/-0.7$ 
$\mathrm{GtC} /$ year/K; indicating less carbon uptake in warmer years consistent with a positive carbon-climate feedback) for the Northern Hemisphere in good agreement with CarbonTracker. The $\mathrm{CO}_{2}$ seasonal cycle, which is driven primarily by terrestrial $\mathrm{CO}_{2}$ uptake and release processes, has also been studied in several other publications (e.g., Reuter et al., 2013; Buchwitz et al., 2015; Lindqvist et al., 2015). Guerlet et al., 2013, analyzed GOSAT XCO $\mathrm{XC}_{2}$ retrievals focusing on the Northern Hemisphere. They identified reduced carbon uptake in the summer of 2010 and found that this is most likely due to the heat wave in Eurasia driving biospheric fluxes and fire emissions. Using a joint inversion of GOSAT and surface data, they estimated an integrated biospheric and fire emission anomaly in AprilSeptember 2010 of $0.89 \pm 0.20 \mathrm{PgC}$ over Eurasia. Basu et al., 2014, studied seasonal variations of $\mathrm{CO}_{2}$ fluxes during 2009-2011 over Tropical Asia using GOSAT, CONTRAIL and IASI data. They found an enhanced source for 2010 and concluded that this is likely due to the biosphere response to aboveaverage temperatures in 2010 and unlikely due to biomass burning emissions. Parazoo et al., 2013, used GOSAT $\mathrm{XCO}_{2}$ and solar induced chlorophyll fluorescence (SIF) retrievals to better understand the carbon balance of southern Amazonia. Ross et al., 2013, used GOSAT data to obtain information on wildfire $\mathrm{CH}_{4}: \mathrm{CO}_{2}$ emission ratios. For flux inversions not only the retrieved greenhouse gas values are relevant but also their error statistics, in particular the reported uncertainties. Chevallier and O'Dell, 2013, analyzed this aspect in the context of $\mathrm{CO}_{2}$ flux inversions using GOSAT XCO retrievals. Detmers et al., 2015, analyzed GOSAT $\mathrm{XCO}_{2}$ to detect and quantify anomalously large climate-related carbon uptake in Australia during the time period end of 2010 to early 2012. Furthermore, a number of publications focused on improving retrieval algorithms including data processing and comparisons with ground-based observations and global models (e.g. Heymann et al., 2012a, 2012b) or on applying existing algorithms to other sensors (e.g., Heymann et al., 2015). Satellite $\mathrm{XCO}_{2}$ retrievals are also used, for example by the European Centre for Medium-Range Weather Forecasts (ECMWF), to characterize atmospheric $\mathrm{CO}_{2}$ at large and synoptic scales and for $\mathrm{CO}_{2}$ forecasting (Massart et al., 2016). Last but not least and despite the fact that none of the existing satellite missions has been optimized to obtain information on anthropogenic $\mathrm{CO}_{2}$ emissions (in contrast to other proposed future missions, in particular CarbonSat (Bovensmann et al., 2010; Velazco 
publications using existing satellite $\mathrm{XCO}_{2}$ products (Kort et al., 2012; Schneising et al., 2013, Reuter et al., 2014b).

130 Nevertheless, not all carbon-related problems which have been addressed can be answered with confidence due to potential issues with the satellite retrievals (in particular remaining biases) and/or transport modelling (e.g., Stephens et al., 2007) as needed to interpret the satellite products (e.g., Chevallier et al., 2010; Deng et al., 2014). An example is the recent effort to quantify European biospheric terrestrial $\mathrm{CO}_{2}$ fluxes. Basu et al., 2013, presented first $\mathrm{CO}_{2}$ surface flux inverse modeling results from GOSAT $\mathrm{XCO}_{2}$ retrievals for various regions including Europe. For Europe their results imply that Europe is a much stronger carbon sink than current knowledge suggests. Chevallier et al., 2014a, used an ensemble of inversion methods and $\mathrm{GOSAT} \mathrm{XCO}_{2}$ retrievals to also derive regional (sub-continental) $\mathrm{CO}_{2}$ surface fluxes. They also found a significantly larger European carbon sink. They conclude that the derived sink is unrealistically large and they argue that this may be due to modelling issues related to long-range transport modelling and/or biases of the satellite retrievals. In particular they argue that errors of the satellite data outside of Europe may adversely influence the

142 European results. To further investigate this European carbon sink issue in detail, Reuter et al., 2014a, used an ensemble of SCIAMACHY and GOSAT $\mathrm{XCO}_{2}$ data products and an inversion method which

144 is not, or at least significantly less, sensitive to the potential issues discussed in Chevallier et al.,

145 2014a. For example, Reuter et al., 2014a, only used satellite $\mathrm{XCO}_{2}$ retrievals over Europe to rule out

146 that non-European satellite data adversely influence the results for the European carbon sink and they

147 also only used short-term (days) transport modelling for satellite data interpretation to minimize

148 potential long-range transport errors. Reuter et al., 2014a, also performed several sensitivity tests to

149 investigate the robustness of their results and to establish a reliable error budget. Based on an

150 extensive analysis they conclude: "We show that the satellite-derived European terrestrial carbon sink 151 is indeed much larger $(1.02+/-0.30 \mathrm{GtC} /$ year in 2010$)$ than previously expected". The value they

152 derived is larger compared to earlier inversion estimates using in-situ observations of $0.47+/-0.50$

153 ("LSCE-39-insitu inversion") or 0.42 +/- 0.25 (“UoE-insitu”) GtC/year for 2010 (Chevallier et al., 154 2014a), or 0.40 +/- $0.42 \mathrm{GtC} /$ year for 2001-2004 (Peylin et al, 2013), which is reported in the recent 
IPCC report (IPCC, 2013). The disagreement with bottom-up estimates is even larger and significant: Schulze et al., 2009, report 0.235 +/- 0.05 GtC/year between 2000 and 2005. These findings of Reuter et al., 2014a, stimulated additional research using satellite and non-satellite $\mathrm{CO}_{2}$ observations (e.g., Feng et al., 2016, and discussion in Houweling et al., 2015) but consensus has not yet been achieved, e.g., Feng et al., 2016, finally conclude: “...we cannot prove or disprove that European ecosystems are taking up a larger-than-expected amount of $\mathrm{CO}_{2}{ }^{\prime}$. Recently, some new research results have been obtained by assimilating new Siberian $\mathrm{CO}_{2}$ observations in CarbonTracker (Kim et al., 2016). They report a European sink strength of $0.75 \pm 0.63 \mathrm{GtC} /$ year for 2008-2009, which temporally overlaps with the range reported by Reuter et al., 2014a, and is significantly larger compared to their reference inversions without these new Siberian observations. On the other hand, based on simultaneous $\mathrm{CO}_{2}$ and $\mathrm{CH}_{4}$ flux inversions using GOSAT-retrieved ratios of total column $\mathrm{CH}_{4}$ and $\mathrm{CO}_{2}$ for 2009 and 2010, Pandey et al., 2016, obtain European terrestrial $\mathrm{CO}_{2}$ fluxes close to zero, in contrast to the results discussed above. Apparently, more research is needed to answer this important European carbon sink question with confidence.

For satellite $\mathrm{XCH}_{4}$ retrievals and the interpretation of these data sets the situation is similar as for $\mathrm{XCO}_{2}$. SCIAMACHY data have already been extensively used to improve our knowledge on atmospheric methane and regional methane emissions prior to the start of the GHG-CCI project (e.g., Buchwitz et al., 2005; Frankenberg et al., 2005; Schneising et al., 2009; Bergamaschi et al., 2007, 2009; Bloom et al., 2010). A more recent research focus has been to investigate the unexpected renewed atmospheric methane increase since 2007 using ground-based and/or satellite data (e.g., Rigby et al., 2008; Dlugokencky et al., 2009; Bergamaschi et al., 2009, 2013; Schneising et al., 2011; Frankenberg et al., 2011; Sussmann et al., 2012; Crevoisier et al., 2013; Houweling et al., 2014; Nisbet et al., 2014; Schaefer et al., 2016). Methane emission estimates have been obtained from GOSAT as discussed in a number of recent publications (e.g., Fraser et al., 2013, 2014, Monteil et al., 2013, Cressot et al., 2014, Alexe et al., 2015; Turner et al., 2015, 2016). In these studies often $\mathrm{CH}_{4}$ retrievals from several satellites have been used (as well as other data, in particular NOAA data), e.g., Monteil et al., 2013, and Alexe et al., 2015, used SCIAMACHY and GOSAT retrievals, Cressot el al., 2014, used 

TES satellite retrievals. Several publications focused on relatively localized methane sources, e.g., in the United States: For example, Schneising et al., 2014, analyzed SCIAMACHY data over major US "fracking" regions and quantified anthropogenic methane emissions and leakage rates and also others used SCIAMACHY data over the US to identify and quantify localized methane emission sources (Kort et al., 2014; Wecht et al., 2014). The SCIAMACHY $\mathrm{XCH}_{4}$ retrievals have also been used to compare with and to improve chemistry-climate models (Shindell et al., 2014, Hayman et al., 2014).

Despite this quite large number of publications it is clear that still much more has to be learned about the various (and changing) sources and sinks of $\mathrm{CO}_{2}$ and $\mathrm{CH}_{4}$. It is obvious that the more accurate and precise the observations are and the longer and denser the observational time series is, the larger their information content. Within the GHG-CCI project a continuous algorithm improvement, re-processing and data product analysis cycle is carried out every year with the goal to deliver each year an improved data set of satellite-derived atmospheric $\mathrm{CO}_{2}$ and $\mathrm{CH}_{4}$ information. The latest data set is called CRDP3. This data set is presented in the following (Sect. 2) including an initial quality assessment by comparison with ground-based observations (Sect. 3) and model comparisons (Sects. 4 and 5) focusing on $\mathrm{CO}_{2}$. A summary and conclusions are given in Sect. 6.

\section{Overview data set CRDP3}

The GHG-CCI latest data set called Climate Research Data Package No. 3 (CRDP3) consists of several satellite-derived atmospheric $\mathrm{CO}_{2}$ and $\mathrm{CH}_{4}$ data products. These data products are classified as (i) GHG-CCI project core products, generated with so-called ECV Core Algorithms (ECAs), and (ii) additional products, generated with so-called Additional Constraints Algorithms (ACAs). The ECA products are $\mathrm{XCO}_{2}$ and $\mathrm{XCH}_{4}$ (see Tabs. 1 and 2) retrieved from satellite nadir mode radiance spectra in the near-infrared / shortwave-infrared (NIR/SWIR) spectral region using appropriate retrieval algorithms. These retrieval algorithms are all based on modelling the observed radiance spectra using a radiative transfer model and corresponding parameters (e.g., vertical profiles of atmospheric $\mathrm{CO}_{2}$, 
$211 \mathrm{CH}_{4}$, temperature, aerosols, etc.) coupled to an inversion method to iteratively optimize selected

212 parameters until the modeled radiance matches the observed radiance spectrum. All retrieval

213 algorithms are based on Optimal Estimation / Bayesian Inference theory (see Rodgers, 2000, for the

214 general theory and Reuter et al., 2010, for a typical example) with the exception of the WFMD

215 algorithms (see Tabs. 1 and 2), which are based on a least-squares fitting combined with a very fast

216 look-up-table scheme (e.g., Buchwitz et al., 2000; Schneising et al., 2011). The algorithms are also

217 using post-processing steps including bias correction and quality filtering and/or assigning a quality

218 flag to each single retrieval (ground pixel) (see information on retrieval Algorithm Theoretical

219 Baseline Documents (ATBDs) given below).

Table 1: Overview GHG-CCI individual ECV Core Algorithms (ECAs) as used for $\mathrm{XCO}_{2}$ retrieval and the generation of the corresponding data product. See main text for a description of baseline and alternative products.

\begin{tabular}{|c|c|c|c|}
\hline \multicolumn{4}{|c|}{ GHG-CCI ECV Core Algorithms (ECAs) for $\mathrm{XCO}_{2}$ retrieval } \\
\hline $\begin{array}{l}\text { Algorithm ID } \\
\text { (Version) }\end{array}$ & Sensor & $\begin{array}{l}\text { Algorithm } \\
\text { Institute }\end{array}$ & $\begin{array}{c}\text { Comment } \\
\text { (Algorithm reference) }\end{array}$ \\
\hline $\begin{array}{c}\text { CO2_SCI_BESD } \\
\text { (v02.01.01) }\end{array}$ & $\begin{array}{l}\text { SCIAMACHY/ } \\
\text { ENVISAT }\end{array}$ & $\begin{array}{c}\text { BESD } \\
\text { IUP, Univ. Bremen, Germany }\end{array}$ & $\begin{array}{l}\text { SCIAMACHY XCO } \mathrm{XC}_{2} \text { baseline product } \\
\text { Coverage: global (land), 1.2003-3.2012 } \\
\text { (Reuter et al., 2011) }\end{array}$ \\
\hline $\begin{array}{c}\text { CO2_SCI_WFMD } \\
(\mathrm{v} 3.9)\end{array}$ & -“" & $\begin{array}{c}\text { WFM-DOAS } \\
\text { IUP, Univ. Bremen, Germany }\end{array}$ & $\begin{array}{l}\text { SCIAMACHY XCO } \mathrm{XCO}_{2} \text { alternative product } \\
\text { Coverage: global (land), 10.2002-4.2012 } \\
\text { (Schneising et al., 2011) }\end{array}$ \\
\hline $\begin{array}{c}\text { CO2_GOS_OCFP } \\
\text { (v6.0) }\end{array}$ & TANSO/GOSAT & $\begin{array}{c}\text { UoL-FP } \\
\text { University of Leicester (UoL), } \\
\text { UK }\end{array}$ & $\begin{array}{l}\text { GOSAT } \mathrm{XCO}_{2} \text { baseline product } \\
\text { Coverage: global, 4.2009-12.2014 } \\
\text { (Cogan et al., 2012) }\end{array}$ \\
\hline $\begin{array}{c}\text { CO2_GOS_SRFP } \\
\text { (v2.3.7) }\end{array}$ & -“"- & $\begin{array}{c}\text { RemoTeC } \\
\text { SRON (Utrecht, Netherlands) \& } \\
\text { KIT (Karlsruhe, Germany) }\end{array}$ & $\begin{array}{l}\text { GOSAT } \mathrm{XCO}_{2} \text { alternative product } \\
\text { Coverage: global, 6.2009-12.2014 } \\
\text { (Butz et al., 2011) }\end{array}$ \\
\hline
\end{tabular}


Table 2: As Tab. 1 but for the GHG-CCI individual $\mathrm{XCH}_{4}$ retrieval algorithms and corresponding data products.

\begin{tabular}{|c|c|c|c|}
\hline \multicolumn{4}{|c|}{ GHG-CCI ECV Core Algorithms (ECAs) for $\mathrm{XCH}_{4}$ retrieval } \\
\hline $\begin{array}{c}\text { Algorithm ID } \\
\text { (Version) }\end{array}$ & Sensor & $\begin{array}{l}\text { Algorithm } \\
\text { Institute }\end{array}$ & $\begin{array}{c}\text { Comment } \\
\text { (Algorithm reference) }\end{array}$ \\
\hline $\begin{array}{c}\text { CH4_SCI_WFMD } \\
\text { (v3.9) }\end{array}$ & $\begin{array}{l}\text { SCIAMACHY/ } \\
\text { ENVISAT }\end{array}$ & $\begin{array}{c}\text { WFM-DOAS } \\
\text { IUP, Univ. Bremen, Germany }\end{array}$ & $\begin{array}{l}\text { SCIAMACHY XCH } \mathrm{XH}_{4} \text { proxy product } \\
\text { (baseline not yet decided) } \\
\text { Coverage: global, 10.2002-12.2011 } \\
\text { (Schneising et al., 2011) }\end{array}$ \\
\hline $\begin{array}{c}\text { CH4_SCI_IMAP } \\
(\mathrm{v} 7.1)\end{array}$ & $-“-$ & $\begin{array}{c}\text { IMAP } \\
\text { SRON (Utrecht, Netherlands) \& } \\
\text { JPL (Padadena, CA, USA) }\end{array}$ & $\begin{array}{l}\text { SCIAMACHY XCH } \mathrm{XH}_{4} \text { proxy product } \\
\text { (baseline not yet decided) } \\
\text { Coverage: global (land), 1.2003-4.2012 } \\
\text { (Frankenberg et al., 2011) }\end{array}$ \\
\hline $\begin{array}{c}\text { CH4_GOS_OCPR } \\
\text { (v6.0) }\end{array}$ & TANSO/GOSAT & $\begin{array}{c}\text { UoL-PR } \\
\text { University of Leicester (UoL), } \\
\text { UK }\end{array}$ & $\begin{array}{c}\text { GOSAT } \mathrm{XCH}_{4} \text { proxy baseline product } \\
\text { Coverage: global, 4.2009-12.2014 } \\
\text { (Parker et al., 2011) }\end{array}$ \\
\hline $\begin{array}{c}\text { CH4_GOS_SRPR } \\
\text { (v2.3.7) }\end{array}$ & -“"- & $\begin{array}{c}\text { RemoTeC } \\
\text { SRON (Utrecht, Netherlands) \& } \\
\text { KIT (Karlsruhe, Germany) }\end{array}$ & $\begin{array}{l}\text { GOSAT } \mathrm{XCH}_{4} \text { proxy alternative product } \\
\text { Coverage: global, 6.2009-12.2014 } \\
\text { (Butz et al., 2010) }\end{array}$ \\
\hline $\begin{array}{c}\text { CH4_GOS_SRFP } \\
\text { (v2.3.7) }\end{array}$ & $-“-$ & $\begin{array}{c}\text { RemoTeC } \\
\text { SRON (Utrecht, Netherlands) \& } \\
\text { KIT (Karlsruhe, Germany) }\end{array}$ & $\begin{array}{c}\text { GOSAT } \mathrm{XCH}_{4} \text { full physics baseline } \\
\text { product } \\
\text { Coverage: global, 6.2009-12.2014 } \\
\text { (Butz et al., 2011) }\end{array}$ \\
\hline $\begin{array}{c}\text { CH4_GOS_OCFP } \\
\text { (v1.0) }\end{array}$ & -“"- & $\begin{array}{c}\text { UoL-PR } \\
\text { University of Leicester (UoL), } \\
\text { UK }\end{array}$ & $\begin{array}{c}\text { GOSAT } \mathrm{XCH}_{4} \text { full physics alternative } \\
\text { product } \\
\text { Coverage: global, 4.2009-12.2014 } \\
\text { (Parker et al., 2011) }\end{array}$ \\
\hline
\end{tabular}


The exploited NIR/SWIR spectral regions contain relevant $\mathrm{CO}_{2}, \mathrm{CH}_{4}$ and (depending on algorithm/product) molecular oxygen $\left(\mathrm{O}_{2}\right)$ absorption lines. $\mathrm{O}_{2}$ is used to get information on the light path and on the dry-air column needed to convert the GHG vertical columns into mole fractions (number density mixing ratio). For sufficiently cloud-free day-side observations these spectra are typically dominated by surface-reflected solar radiation and are therefore sensitive to near-surface greenhouse gas concentration variations.

Currently, the corresponding GHG-CCI ECA products are derived from SCIAMACHY/ENVISAT and TANSO/GOSAT. In this publication we focus on the GHG-CCI CRDP3 ECA products. An overview on the additional GHG-CCI ACA products is given in Buchwitz et al., 2015, and details are given on the GHG-CCI website (http://www.esa-ghg-cci.org/), in particular in the corresponding ACA product tables as given on the GHG-CCI main data products website (http://www.esa-ghgcci.org/sites/default/files/documents/public/documents/GHG-CCI_DATA.html). In short, ACA products are not (or typically not) sensitive to near-surface GHG variations but to variations in upper atmospheric layers, i.e., layers above the planetary boundary layer. They therefore provide complementary additional information (compared to ECAs) on atmospheric $\mathrm{CO}_{2}$ and $\mathrm{CH}_{4}$. ACA products are mid/upper tropospheric $\mathrm{CO}_{2}$ and $\mathrm{CH}_{4}$ mixing ratios from IASI (Crevoisier et al., 2009a, 2009b, 2013), upper tropospheric / stratospheric vertical $\mathrm{CH}_{4}$ profiles from MIPAS (Laeng et al., 2015), stratospheric $\mathrm{CH}_{4}$ and $\mathrm{CO}_{2}$ profiles from SCIAMACHY solar occultation observations (Noël et al., 2012, 2016) and stratospheric $\mathrm{CO}_{2}$ profiles from ACE-FTS (Foucher et al., 2009).

An overview about the GHG-CCI ECAs and corresponding data products is given in Tab. 1 for $\mathrm{XCO}_{2}$ and in Tab. 2 for $\mathrm{XCH}_{4}$. As can be seen, there are two algorithms for each data product. For example, there are two algorithms for $\mathrm{XCO}_{2}$ from SCIAMACHY and two algorithms for $\mathrm{XCO}_{2}$ from GOSAT, resulting in four $\mathrm{XCO}_{2}$ products generated independently with different algorithms. We encourage users of our data products to take advantage of this ensemble of products which can even be extended using additional (i.e., non-GHG-CCI) products generated elsewhere, most notably in Japan (NIES products (Yoshida et al., 2013; Oshchepkov et al., 2011, 2013) and in the USA (NASA ACOS product 
(O’Dell et al., 2012; Crisp et al., 2012)). The main reason for this recommendation is that even small

(and typically difficult to characterize) systematic errors in the $\mathrm{XCO}_{2}$ products can lead to quite large errors when using $\mathrm{XCO}_{2}$ to get information on $\mathrm{CO}_{2}$ surface fluxes (emission or uptake). This is because the $\mathrm{CO}_{2}$ background concentration is quite high and even large sources and sinks typically results in only small $\mathrm{XCO}_{2}$ variations (see, e.g., Reuter et al., 2014a). Using an ensemble of products generated with independent algorithms enables one to determine the robustness of the source/sink findings with respect to algorithmic choices which have to be made when implementing a retrieval algorithm and also permits one to assign more realistic error bars to quantitative source/sink results (see, for example, Reuter et al., 2014a, using an ensemble of $\mathrm{XCO}_{2}$ data products to obtain information on the strength of the European carbon sink).

However, we acknowledge that this is a major effort which cannot be undertaken by all users, e.g., due to time, financial or other constraints. For these users we aim at giving recommendations on which product to use if they can or want to use only one (or a few) products. We do this by identifying socalled baseline (or recommended) products (see also Buchwitz et al., 2015, and Dils et al., 2014, for our initial "Round Robin" attempt to identify "best" algorithms and corresponding data products). As can be seen from Tabs. 1 and 2, we have identified baseline algorithms/products for all products except for SCIAMACHY $\mathrm{XCH}_{4}$ (as both products still suffer from degraded quality as discussed below). Note that a baseline product is not necessarily significantly better than the corresponding alternative product because, as one may expect, different algorithms have different strengths and weaknesses. Often we found that data products differ (e.g., at the different individual validation sites) but it is not clear which one is better (e.g., if the overall agreement with the validation network is on average equivalently good). Therefore, for products where this is the case, the baseline product is for some products simply the product which has been agreed upon between the different data providing institutions. Note that the definition of "better" also depends on the application. For example, for

283 SCIAMACHY $\mathrm{XCO}_{2}$, the BESD product has been declared as baseline product and the WFMD

284 product as alternative product because BESD has typically lower systematic errors / biases, and better precision, i.e., less random errors (as confirmed by the results shown in Sect. 3.1) but much less data 
(approx. 50\% as also shown in Sect. 3.1) compared to the WFMD product. For some applications with relevant requirements on spatio-temporal coverage, the WFMD product may therefore be the better suited or even the only choice provided the biases are small enough for the target application. Within the GHG-CCI project quality assessment is an ongoing effort with one of the goals to confirm or change the classification of algorithms/products as "baseline" or "alternative", depending on future algorithm improvements and corresponding future data quality.

Note that two additional $\mathrm{XCO}_{2}$ and $\mathrm{XCH}_{4}$ products are available from the GHG-CCI website not listed in Tabs. 1 and 2. These are the Ensemble Median Algorithm (EMMA) $\mathrm{XCO}_{2}$ (Reuter et al., 2013) and $\mathrm{XCH}_{4}$ products. These products are also Level 2 products (i.e., non-gridded individual ground pixel swath products) as the other products listed in Tabs. 1 and 2 but they have been generated by merging individual products from SCIAMACHY and GOSAT. They are not further discussed here (for details see Reuter et al., 2013, and Buchwitz et al., 2016).

As can be seen from Tab. 2, the number of $\mathrm{XCH}_{4}$ algorithms/products is even larger than for $\mathrm{XCO}_{2}$. The reason is that there are two types of $\mathrm{XCH}_{4}$ algorithms for the GOSAT products, the so-called (light path) "proxy" (PR) algorithms and the "full-physics" (FP) algorithms (see Schepers et al., 2012, Buchwitz et al., 2015, Parker et al., 2015, and references given therein for details). In short, $\mathrm{XCH}_{4} \mathrm{PR}$ algorithms convert retrieved $\mathrm{CH}_{4}$ columns into $\mathrm{XCH}_{4}$ by using dry-air columns obtained from simultaneously retrieved $\mathrm{CO}_{2}$ column in combination with modelled $\mathrm{CO}_{2}$ column to correct for $\mathrm{CO}_{2}$ column variations (the PR algorithm require that atmospheric $\mathrm{CH}_{4}$ columns typically vary more than $\mathrm{CO}_{2}$ columns (in relative, i.e., percentage, terms)). The advantage of the PR method is that systematic column retrieval errors (e.g., light path errors due to unaccounted scattering by aerosols and clouds but also some instrument errors) cancel to some extent when the ratio of the retrieved $\mathrm{CH}_{4}$ and $\mathrm{CO}_{2}$ columns is computed. The disadvantage is that this method needs sufficiently accurate $\mathrm{CO}_{2}$ model

311 simulations to correct for $\mathrm{CO}_{2}$ variations. The FP method, which does not have this disadvantage, aims 312 at considering aerosol and cirrus effects explicitly by considering (as good as possible) the "full 313 physics" of the atmospheric radiative transfer. This means that FP methods aim at solving a much 
more challenging radiative transfer and inversion problem and, therefore, they do not have to rely on accurate $\mathrm{CO}_{2}$ modelling. This shows that both methods have different strengths and weaknesses. As a consequence the resulting data products have different characteristics (typically PR products contain much more data points compared to FP products, see Sect. 3.2). Because these two type of methane algorithms/products are significantly different they are classified separately as baseline or alternative as shown in Tab. 2.

Despite the fact that all algorithms are based on similar principles (namely on optimizing radiative transfer model and other parameters until a "good" match between the measured and modelled radiances has been obtained), they differ in many details. It is out of the scope of this manuscript to explain each algorithm in detail. Instead we refer to the documentation as given on the GHG-CCI website, in particular to the Algorithm Theoretical Baseline Documents (ATBDs) (see links given in the product tables of the GHG-CCI main data products website (http://www.esa-ghgcci.org/sites/default/files/documents/public/documents/GHG-CCI_DATA.html)).

Figure 1 shows time series of northern hemispheric $\mathrm{XCO}_{2}$ as obtained from all four GHG-CCI $\mathrm{XCO}_{2}$ retrieval algorithms (see Tab. 1). As can be seen, all $\mathrm{XCO}_{2}$ products clearly show an approximately 2 $\mathrm{ppm} /$ year $\mathrm{CO}_{2}$ increase (due to anthropogenic $\mathrm{CO}_{2}$ emissions) and the atmospheric $\mathrm{CO}_{2}$ seasonal cycle (primarily due to regular uptake and release of $\mathrm{CO}_{2}$ by the terrestrial biosphere). The SCIAMACHY products cover (essentially) the entire ENVISAT time period from end of 2002 (WFMD product) or beginning of 2003 (BESD product) to April 2012. The GOSAT CRDP3 products cover the time period mid 2009 to end of 2014. As can be seen, the agreement between the different time series is within about 1-2 ppm. Note that perfect agreement is not to be expected, e.g., due to differences in spatiotemporal sampling and vertical sensitivity (see the following sections for quantitative assessments). To

338 obtain quantitative estimates of the characteristics of the various data products in terms of random and 339 systematic errors and long-term stability one has to compare the individual products with appropriate 340 high-quality reference data (see Sect. 3) and one also has to compare spatial pattern (Sect. 4). In Sect. 3 we present comparisons of the satellite products with ground-based observations at selected 
342 locations and in Sect. 4 we present comparison with global models. Note that we also aim at model

343 independent quantitative comparisons of the global satellite data via the Ensemble Median Algorithm

344 EMMA (Reuter et al., 2013). For the latest EMMA assessment results (not shown here) see Buchwitz

345 et al., 2016.

346

347 Figure 2 shows time series of northern hemispheric $\mathrm{XCH}_{4}$. As can be seen, the agreement among the

348 various products is less good (in relative terms) compared to $\mathrm{XCO}_{2}$ in particular for the two

349 SCIAMACHY $\mathrm{XCH}_{4}$ products which also deviate significantly from the GOSAT $\mathrm{XCH}_{4}$ products in

350 particular for 2010 and later years. This is potentially due to SCIAMACHY detector issues whose

351 impact on the data quality is still large but hopefully can be (further) mitigated in future versions of the

352 SCIAMACHY products. The seasonality of the GOSAT $\mathrm{XCH}_{4}$ OCFP product, which is a new product

353 from Univ. Leicester, deviates somewhat from the other products. Also this aspect needs further

354 investigation.

355 


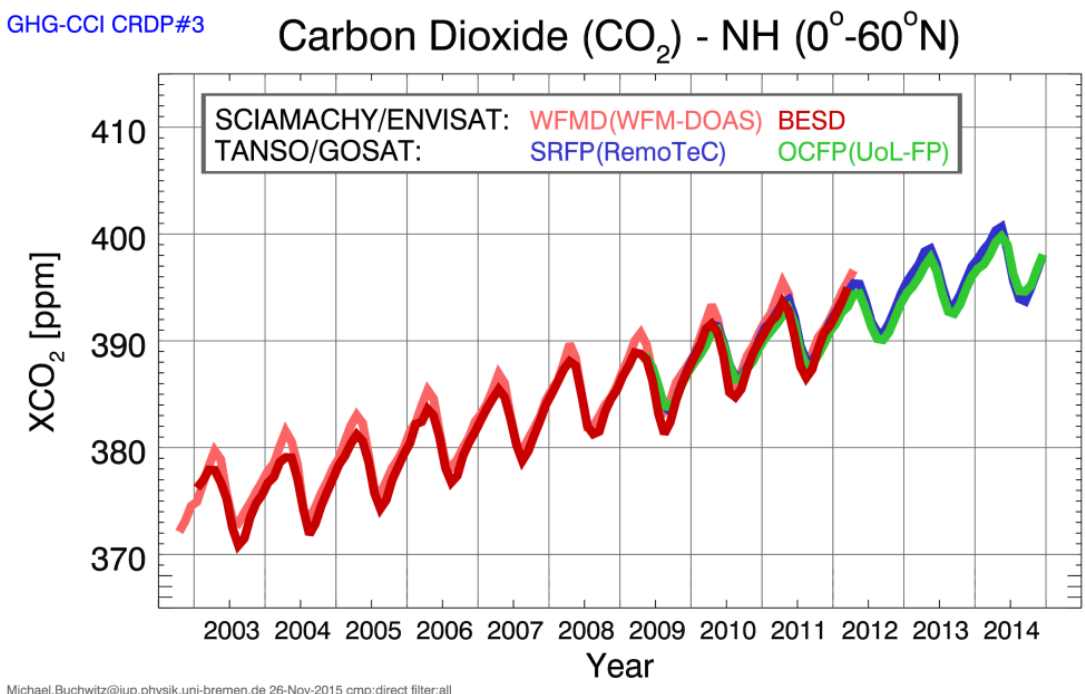

358 Figure 1: Timeseries of northern hemispheric $\mathrm{XCO}_{2}$ of the four GHG-CCI CRDP3 $\mathrm{XCO}_{2}$ data products (CO2_SCI_WFMD (light red), CO2_SCI_BESD (red), CO2_GOS_SRFP (blue) and $60^{\circ} \mathrm{N}$ for each month.

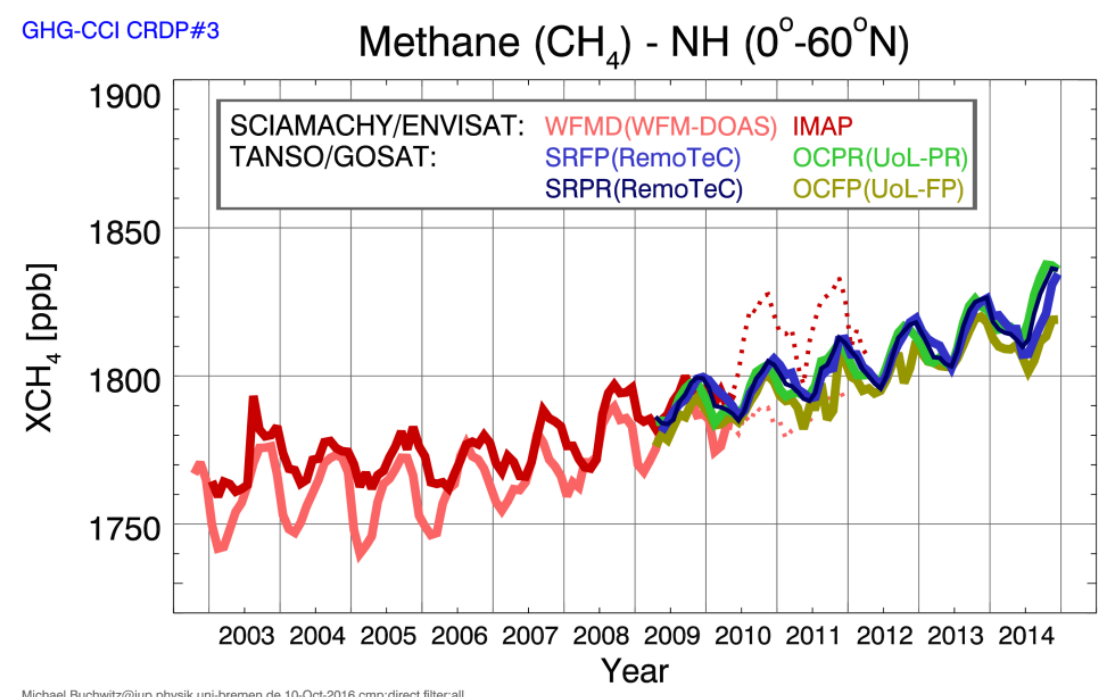

Figure 2: Timeseries of northern hemispheric $\mathrm{XCH}_{4}$ of the six GHG-CCI CRDP3 $\mathrm{XCH}_{4}$ data products (see inset) obtained by averaging all satellite retrievals north of the equator up to $60^{\circ} \mathrm{N}$ for each month. Note that the SCIAMACHY products after approx. mid 2010 (see dotted lines) suffer from currently still unresolved issues probably related to detector degradation. 
370 In the following section a comparison of these $\mathrm{XCO}_{2}$ and $\mathrm{XCH}_{4}$ products with ground-based reference

371 observations is presented which has been carried out to obtain initial quantitative information on the 372 data quality. Note that a more detailed comparison with ground-based data is presented in Dils et al., 3732016.

\section{Comparisons with ground-based observations}

The ground-based Total Carbon Column Observing Network (TCCON) has been designed for validation of satellite $\mathrm{XCO}_{2}$ and/or $\mathrm{XCH}_{4}$ retrievals (Wunch et al., 2011a, 2011b) and TCCON data have been used extensively also in the past for comparison of GHG-CCI data products (e.g., Dils et al., 2014, Buchwitz et al., 2015). TCCON is a network of ground-based Fourier Transform Spectrometers recording direct solar spectra in the near-infrared spectral region. From these spectra, accurate and precise column-averaged abundance of $\mathrm{CO}_{2}, \mathrm{CH}_{4}$ and other atmospheric data products are retrieved. The TCCON $\mathrm{XCO}_{2}$ and $\mathrm{XCH}_{4}$ data products version GGG2014 as used for this study (Wunch et al., 2015) have been downloaded from the TCCON data archive (http://tccon.ornl.gov).

Within GHG-CCI we use several somewhat different methods for satellite - TCCON comparison (see Buchwitz et al., 2016) including methods developed and applied independently by each data provider to his/her product. Two methods are applied to all CRDP3 $\mathrm{XCO}_{2}$ and $\mathrm{XCH}_{4}$ products, the method developed by the GHG-CCI validation team (Dils et al. 2016) and a somewhat simplified approach developed and used primarily for Quality Control / Quality Assurance (QC/QA) purposes. Overall it has been found that all validation methods result in similar conclusions concerning the overall data quality of the CRDP3 ECA products, which demonstrates the robustness of the findings (Buchwitz et al., 2016). In the following we present the QC/QA approach and its results. and $\mathrm{XCH}_{4}$ TCCON data products from six TCCON sites, two in the USA, two in Europe and two in 
Australia (see Tab. 3). For each ECA product and each of the selected TCCON sites we have performed detailed comparisons of individual (but also averaged) satellite soundings (ground pixels) using a co-location criterion of 2 hours temporally and $4^{\circ} \times 4^{\circ}$ latitude/longitude spatially. To minimize the impact of different a priori information used for the retrievals, common $\mathrm{CO}_{2}$ and $\mathrm{CH}_{4}$ profiles have been used for comparison using TCCON a priori profiles as common profiles for the comparisons (see also Dils et al., 2014, using the same approach).

Table 3: TCCON sites and corresponding data coverage as used for comparison with the satellite $\mathrm{XCO}_{2}$ and $\mathrm{XCH}_{4}$ data products. The "Time coverage" corresponds to the time coverage of the data products at the time of data access (6-Oct-2015, except Bremen and Bialystok: 20-Nov-2015).

\begin{tabular}{|c|c|c|c|c|c|}
\hline \multicolumn{6}{|c|}{ TCCON validation sites } \\
\hline $\begin{array}{l}\text { Location } \\
\text { (TCCON data product } \\
\text { reference) }\end{array}$ & $\begin{array}{l}\text { Site } \\
\text { ID }\end{array}$ & $\begin{array}{c}\text { Latitude } \\
\text { [deg] }\end{array}$ & $\begin{array}{c}\text { Longitude } \\
\text { [deg] }\end{array}$ & $\begin{array}{c}\text { Altitude } \\
\text { [km] }\end{array}$ & $\begin{array}{c}\text { Time coverage } \\
\text { MM/YYYY-MM/YYYY }\end{array}$ \\
\hline $\begin{array}{l}\text { ParkFalls, USA } \\
\text { (Wennberg et al., 2014a) }\end{array}$ & PAR & 45.945 & -90.273 & 0.442 & $06 / 2004-12 / 2014$ \\
\hline $\begin{array}{l}\text { Lamont, USA } \\
\text { (Wennberg et al., 2014b) }\end{array}$ & LAM & 36.604 & -97.486 & 0.320 & $07 / 2008-12 / 2014$ \\
\hline $\begin{array}{l}\text { Bremen, Germany } \\
\text { (Notholt et al., 2014) }\end{array}$ & BRE & 53.104 & 8.850 & 0.027 & $01 / 2007-10 / 2014$ \\
\hline $\begin{array}{l}\text { Bialystock, Poland } \\
\text { (Deutscher et al., 2014) }\end{array}$ & BIA & 53.231 & 23.025 & 0.183 & $03 / 2009-10 / 2014$ \\
\hline $\begin{array}{l}\text { Darwin, Australia } \\
\text { (Griffith et al., 2014a) }\end{array}$ & DAR & -12.425 & 130.891 & 0.030 & $08 / 2005-09 / 2014$ \\
\hline $\begin{array}{l}\text { Wollongong, Australia } \\
\text { (Griffith et al., 2014b) }\end{array}$ & WOL & -34.406 & 150.879 & 0.030 & $06 / 2008-09 / 2014$ \\
\hline
\end{tabular}


When interpreting satellite-TCCON differences one also has to consider the uncertainty of the TCCON data products. TCCON uncertainties are reported in the TCCON data product files for each individual observation and these uncertainties have been used, e.g., to avoid using TCCON data with

411 large reported errors. However, what is also needed, in particular to compute systematic satelliteTCCON differences across several sites (see, e.g., summary values for regional and seasonal biases in

413 Tabs. 4 and 5) is an estimate of the TCCON site-to-site bias and/or an estimate of the TCCON

414 uncertainty after averaging many TCCON retrievals. Site-to-site biases for TCCON products are 415 reported in Wunch et al., 2010. As shown in Wunch et al., 2010, the uncertainty of the TCCON data 416 products is typically $0.4 \mathrm{ppm}$ for $\mathrm{XCO}_{2}$ (1-sigma) and $4 \mathrm{ppb}$ (1-sigma) for $\mathrm{XCH}_{4}$ (see also the 417 discussion of this and corresponding implications for interpreting satellite - TCCON comparisons as reported in Dils et al., 2014, and Buchwitz et al., 2015). Due to these uncertainties / potential errors of the TCCON data (but also for other reasons, e.g., non-perfect spatio-temporal co-location) the estimated systematic and random errors of the satellite retrievals as reported here have to be interpreted as upper limit estimates (because we assume here that the TCCON site-to-site bias is zero), i.e., the satellite data product errors are likely smaller than reported here, at least at the TCCON sites. On the other hand the TCCON network is quite sparse and does not cover all geophysical conditions. For example, for the $\mathrm{XCO}_{2}$ products it has been identified that differences between satellite products located far away from TCCON sites may differ by somewhat larger amounts than the TCCON validation suggests (e.g., Reuter et al., 2013). Because of these potential overestimation (neglection of TCCON site-to-site bias) / underestimation (TCCON does not capture all situation) issues we interpret the differences to TCCON reported here as a reasonable estimate of the real error (which can be compared with the user requirements) without taking the uncertainty of the TCCON retrievals explicitly into account, i.e., we assume that underestimation and overestimation effects cancels to a large extent (at least on average).

As shown in the following two sub-sections, we compare the achieved performance with the required 434 performance as specified by GCOS (GCOS, 2011) and with the typically more demanding and more detailed requirements as specified in the GHG-CCI User Requirements Document (URD, Chevallier et 
„Tropospheric $\mathrm{CO}_{2}$ column“ and „Tropospheric $\mathrm{CH}_{4}$ column“ in mole fraction (mixing ratio) units

(e.g., ppm for $\mathrm{CO}_{2}$ ). In this manuscript we interpret the GCOS requirements as listed in GCOS, 2011, as requirements for $\mathrm{XCO}_{2}$ and $\mathrm{XCH}_{4}$.

Table 4: Comparison results for product CO2_SCI_BESD with $\mathrm{TCCON} \mathrm{XCO}_{2}$ at six TCCON sites. In the top part of the table results are listed per TCCON site. Reported in column "Bias" are the regional and seasonal biases (see main text for details), the "Scatter", which is the standard deviation of satellite-TCCON difference (based on the individual satellite soundings, i.e., ground pixel) and "RepUncert" (reported uncertainty), which is the mean value of the reported uncertainty as given in the satellite product files for each single sounding. "UncRat" is the uncertainty ratio, which is the ratio of RepUnc and Scatter. Values close to unity indicate that the reported uncertainty is (on average) reliable. "Trend" characterises the long-term stability as obtained by fitting a straight line to the satellite minus TCCON differences covering the entire time series. The listed trend error is the 3sigma uncertainty of the slope of the fitted line. Nobs are the number of individual satellite soundings compared to TCCON. In the bottom part of the table summary values are listed for each parameter (the sum or the mean and/or the standard deviation). See main text for details.

\begin{tabular}{|c|c|c|c|c|c|c|}
\hline \multirow[t]{2}{*}{ Site ID } & \multicolumn{2}{|c|}{ Bias [ppm] } & \multirow{2}{*}{$\begin{array}{r}\text { Scatter } \\
{[p p m]}\end{array}$} & \multirow{2}{*}{$\begin{array}{c}\text { RepUnc } \\
\text { [ppm] } \\
\text { (UncRat [-]) }\end{array}$} & \multirow{2}{*}{$\begin{array}{c}\text { Trend } \\
\text { (Stability) } \\
\text { [ppm/year] }\end{array}$} & \multirow[t]{2}{*}{ Nobs [-] } \\
\hline & Regional & Seasonal & & & & \\
\hline PAR & -0.2 & 0.8 & 2.0 & $2.1(1.0)$ & $0.14+/-0.04$ & 2931 \\
\hline LAM & -0.3 & 0.7 & 1.7 & $1.9(1.1)$ & $-0.01+/-0.05$ & 12003 \\
\hline BRE & -0.3 & 0.8 & 1.8 & $2.5(1.4)$ & $-0.13+/-0.13$ & 1036 \\
\hline BIA & -0.2 & 1.0 & 2.0 & $1.9(1.0)$ & $0.03+/-0.17$ & 1124 \\
\hline DAR & -0.5 & 0.9 & 1.8 & $1.7(0.9)$ & $-0.02+/-0.04$ & 7323 \\
\hline WOL & 0.5 & 0.6 & 2.2 & $2.1(0.9)$ & $-0.07+/-0.11$ & 2389 \\
\hline \multicolumn{6}{|c|}{ Summary: } & \\
\hline Sum & & & & & & 26806 \\
\hline Mean & -0.2 & 0.8 & 1.9 & $2.0(1.1)$ & $-0.01+/-0.09$ & \\
\hline StdDev & 0.4 & & & & & \\
\hline
\end{tabular}


Table 5: As Tab. 4 but for product CH4_SCI_WFMD.

\begin{tabular}{|l|c|c|c|c|c|c|}
\hline \multirow{2}{*}{ Site ID } & \multicolumn{2}{|c|}{ Bias [ppb] } & $\begin{array}{c}\text { Scatter } \\
\text { [ppb] }\end{array}$ & $\begin{array}{c}\text { RepUnc [ppb] } \\
\text { (UncRat [-] })\end{array}$ & $\begin{array}{c}\text { Trend } \\
\text { (Stability) } \\
\text { [ppb/year] }\end{array}$ & Nobs [-] \\
\cline { 2 - 6 } & Regional & Seasonal & & & & \\
\hline PAR & 5.0 & 19.6 & 78.2 & $67.3(0.9)$ & $0.77+/-0.84$ & 11079 \\
\hline LAM & 4.5 & 10.5 & 75.1 & $84.1(1.1)$ & $0.23+/-2.00$ & 18725 \\
\hline BIA & 2.9 & 18.4 & 91.8 & $85.8(0.9)$ & $-1.86+/-4.80$ & 1512 \\
\hline DAR & -18.1 & 17.2 & 67.9 & $82.7(1.2)$ & $-1.87+/-1.38$ & 10580 \\
\hline WOL & -16.2 & 16.4 & 88.0 & $82.0(0.9)$ & $7.73+/-5.34$ & 2832 \\
\hline & & 18.9 & 88.8 & $84.2(0.9)$ & $6.88+/-7.62$ & 46958 \\
\hline Sum & & & & & & \\
\hline Mean & -2.6 & 16.8 & 81.6 & $81.0(1.0)$ & $1.98+/-3.66$ & \\
\hline StdDev & 11.3 & & & & & \\
\hline
\end{tabular}

\section{1 $\mathrm{XCO}_{2}$ comparisons with TCCON}

Figure 3 shows as an example a comparison of the CO2_SCI_BESD product with TCCON $\mathrm{XCO}_{2}$ retrievals at Lamont, Oklahoma, USA. As can be seen, several figures of merit are listed in Fig. 3. They have been defined and computed for quantitative characterization of systematic and random errors of the satellite products and to determine if there are linear trends in the satellite-TCCON differences, i.e., to assess the long-term stability of the satellite products. We also aim at validating the reported uncertainty, which is given in the GHG-CCI data products for each single retrieval (i.e., for each individual ground pixel). This has been done by computing the ratio of the mean value of the reported uncertainty to the standard deviation of the difference to TCCON. Figures such as Fig. 3 have been generated for all ECA $\mathrm{XCO}_{2}$ products and all selected TCCON sites (not shown). The most important figures of merit for product CO2_SCI_BESD at all six TCCON sites are presented in Tab. 

deviation of the results obtained at the individual TCCON sites). The summary results for all four $\mathrm{XCO}_{2}$ products are listed in Tab. 6.

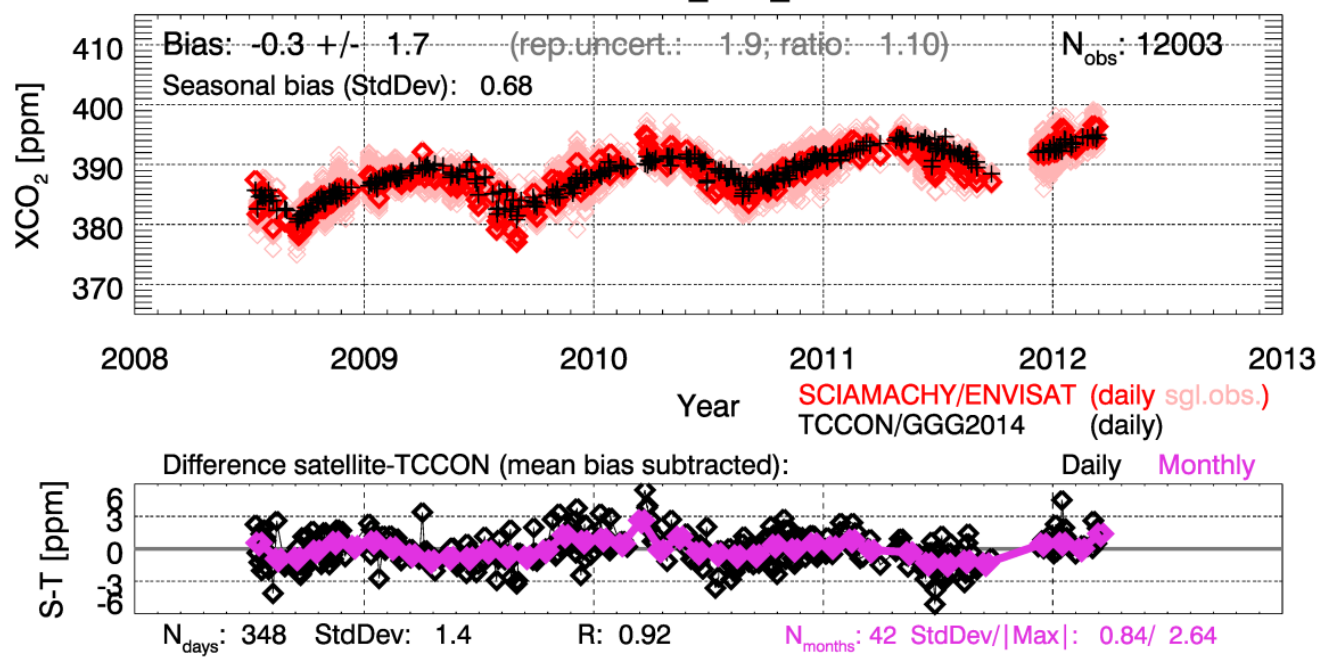

Figure 3: Comparison of product CO2_SCI_BESD with $\mathrm{TCCON} \mathrm{XCO}_{2}$ at TCCON site Lamont, observations ("slg. obs.”) and red for daily averages (co-location criterion: +/- 4 degrees, +/- 2 hours). TCCON $\mathrm{XCO}_{2}$ is shown in black. Listed are several figures of merit: "Bias" (mean +/- standard deviation of the difference of the individual satellite retrievals and TCCON), "Seasonal bias" (standard deviation of differences for 3-month time periods), "Nobs" (number of individual satellite retrievals) and in grey the mean value of the reported uncertainty of the individual $\mathrm{XCO}_{2}$ retrievals ("rep. uncert.") and the "ratio" of the reported uncertainty and the standard deviation of the difference to TCCON. Bottom: $\mathrm{XCO}_{2}$ difference at daily (black) and monthly (pink) resolution. The listed key figures of merit are also shown in Tab. 4 along with the corresponding values obtained at other 
Table 6: Overall TCCON comparison results for the GHG-CCI $\mathrm{XCO}_{2}$ products. The results for product CO2_SCI_BESD have been obtained from Tab. 4 (the corresponding tables for the other three products are not shown here). "Systematic error" lists the regional and seasonal biases and, in

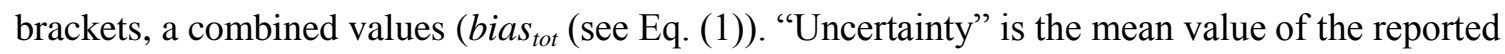
uncertainty and uncertainty ratio "UncRat" (in brackets) is defined as for Tab. 4. Also listed is the "Trend" (with 3-sigma uncertainty), "Offset" (the mean difference relative to all TCCON sites) and the number of satellite soundings ("Nobs") compared to TCCON. At the bottom the corresponding requirements are listed based on GCOS, 2011, and on the GHG-CCI User Requirements Document (URD) (specified as Goal (G), Breakthrough (B) and Threshold (T)) (Chevallier et al., 2014b). Note that the GCOS requirements are target (maximum) requirements, whereas the URD threshold requirements are minimum requirements. The URD requirement for the systematic error is therefore much more demanding than the GCOS requirement but the stability requirements are identical. Note that the uncertainty of the TCCON reference data used to obtain the estimates listed here is about 0.4 $\operatorname{ppm}(1$-sigma).

\begin{tabular}{|c|c|c|c|c|c|}
\hline Product & $\begin{array}{c}\text { Systematic } \\
\text { error [ppm] } \\
\text { Regional, } \\
\text { seasonal } \\
\text { (combined) }\end{array}$ & $\begin{array}{c}\text { Uncertainty } \\
\text { (Random } \\
\text { error) [ppm] } \\
\text { (UncRat) }\end{array}$ & $\begin{array}{c}\text { Trend } \\
\text { (Stability) } \\
\text { [ppm/year] }\end{array}$ & $\begin{array}{l}\text { Offset } \\
\text { [ppm] }\end{array}$ & Nobs [-] \\
\hline CO2_SCI_BESD & $0.4,0.8(0.9)$ & $1.9(1.1)$ & $-0.01+/-0.09$ & -0.2 & 26806 \\
\hline CO2_SCI_WFMD & $0.6,1.1(1.3)$ & $3.0(1.1)$ & $0.01+/-0.10$ & 0.6 & 50087 \\
\hline CO2_GOS_OCFP & $0.3,0.5(0.6)$ & $1.7(1.4)$ & $-0.11+/-0.14$ & 0.1 & 6139 \\
\hline CO2_GOS_SRFP & $0.6,0.5(0.8)$ & $1.9(1.0)$ & $-0.08+/-0.11$ & 0.1 & 6795 \\
\hline $\begin{array}{l}\text { Required } \\
\text { G / B / T }\end{array}$ & $\begin{array}{c}<1 \\
<0.2 / 0.3 / 0.5\end{array}$ & $\begin{array}{c}- \\
<1 / 3 / 8\end{array}$ & $\begin{array}{c}<0.2 \\
<0.2 / 0.3 / 0.5\end{array}$ & \multicolumn{2}{|c|}{$\begin{array}{l}\text { GHG-CCI URD } \\
\text { (Chevallier et al., } \\
\text { 2014b) }\end{array}$} \\
\hline
\end{tabular}


507 As can be seen from Tab. 6, column "Systematic error", the estimated regional bias of product

508 CO2_SCI_BESD is $0.4 \mathrm{ppm}$ and the estimated seasonal bias is $0.8 \mathrm{ppm}$. The regional bias has been

509 estimated as standard deviation of the biases obtained at the individual TCCON sites ("station-to-

510 station bias") (see Tab. 4 for CO2_SCI_BESD). The seasonal bias is the mean value (over all TCCON

511 sites) of the standard deviation of 3-monthly biases as obtained at the individual TCCON sites (see

512 Dils et al., 2014, for a similar estimation of biases). The method of computing standard deviations

513 neglects a possible overall offset relative to TCCON (listed separately in Tab. 6) but this is in line with

514 the GHG-CCI User Requirements Document (URD, Chevallier et al., 2014b) which explains that

515 spatio-temporal variations of biases are critical but overall (constant) offsets can be dealt with when

516 using the satellite data products for inverse modelling (in other words "relative accuracy" is more

517 important than "absolute accuracy"; note that in this manuscript the terms "accuracy", "systematic

518 error" and "bias" have the same meaning). Furthermore, a combined systematic error, bias $_{\text {tot }}$, is listed

519 in column "Systematic error" in brackets, which has been computed from the regional and seasonal

520 biases as follows:

$$
\text { bias }_{\text {tot }}=\sqrt{\text { bias }_{\text {reg }}^{2}+\text { bias }_{\text {seas }}^{2}}
$$

As can be seen from Tab. 6, the biases of the other products are quite similar. All values are below 1 ppm except for product CO2_SCI_WFMD, where the total bias is $1.25 \mathrm{ppm}$. Tab. 6 also lists the required performance. As can be seen, all products (with the exception of CO2_SCI_WFMD, which has the advantage of providing the largest number of data points) meet the GCOS systematic error requirement (of better than $1 \mathrm{ppm}$ ) but not the much more demanding requirement as listed in the GHG-CCI URD (better than $0.5 \mathrm{ppm}$ ). However, as already mentioned above, one also has to consider the uncertainty of the TCCON retrievals (see also Buchwitz et al., 2015, for a discussion of this aspect). The systematic and random errors of single TCCON data are typically $0.4 \mathrm{ppm}$ for $\mathrm{XCO}_{2}(1-$

532 sigma) and $4 \mathrm{ppb}$ (1-sigma) for $\mathrm{XCH}_{4}$ (see Notholt et al., 2012, based on Wunch et al., 2010). 

and adding this (in a root-sum-square manner (e.g., Eq. (1)) to the 0.5 ppm URD requirement yields 0.64 ppm, i.e., a number somewhat larger than the overall bias for product CO2_GOS_OCFP $(0.58$ ppm). It is therefore possible that product CO2_GOS_OCFP even meets the demanding GHG-CCI URD threshold systematic error requirement of better than $0.5 \mathrm{ppm}$.

Table 6 also lists mean values of the reported uncertainty (essentially the random error component of the single ground pixel satellite retrievals) and the "uncertainty ratio" ("UncRat", in brackets), i.e., the ratio of reported uncertainty and standard deviation of the difference to TCCON. For the CO2_SCI_BESD product the reported uncertainty is $1.9 \mathrm{ppm}$ (on average) and the uncertainty ratio is 1.1 providing confidence that the reported uncertainty is realistic (at least on average). This is also true for the other products with the exception of CO2_GOS_OCFP which appears to overestimate the uncertainty by about $40 \%$ on average, i.e., the reported uncertainty is quite conservative. As can also be seen, all products clearly meet the GHG-CCI URD breakthrough requirement of better than $3 \mathrm{ppm}$ or are very close to meeting it (for product CO2_SCI_WFMD the estimated precision is $3.0 \mathrm{ppm}$ ).

Table 6 also lists the linear trend and its uncertainty, which has been determined by fitting a straight line to the individual satellite minus TCCON differences (after removal of a possible seasonal cycle obtained by fitting a linear combination of harmonics (sine and cosine functions) to the data). The trend uncertainty as given here is the 3-sigma uncertainty of the estimated trend. Assuming that only trends which are larger than their uncertainty are significant, one can see that none of the trends is significant. This indicates very good long-term stability (or, more precisely, the absence of a linear drift) of all satellite $\mathrm{XCO}_{2}$ products (note that even the goal requirement of better than $0.2 \mathrm{ppm} /$ year is met for all products). 


\section{2 $\mathrm{XCH}_{4}$ comparisons with TCCON}

561 Similar comparisons as presented in the previous sub-section have also been performed for the $\mathrm{XCH}_{4}$

562 ECA products. Detailed example results for product CH4_SCI_WFMD are shown in Fig. 4 and Tab.

563 5. The most relevant figures of merit, defined as for $\mathrm{XCO}_{2}$ (see previous section), are summarized

564 along with the results for the other products in Tab. 7.

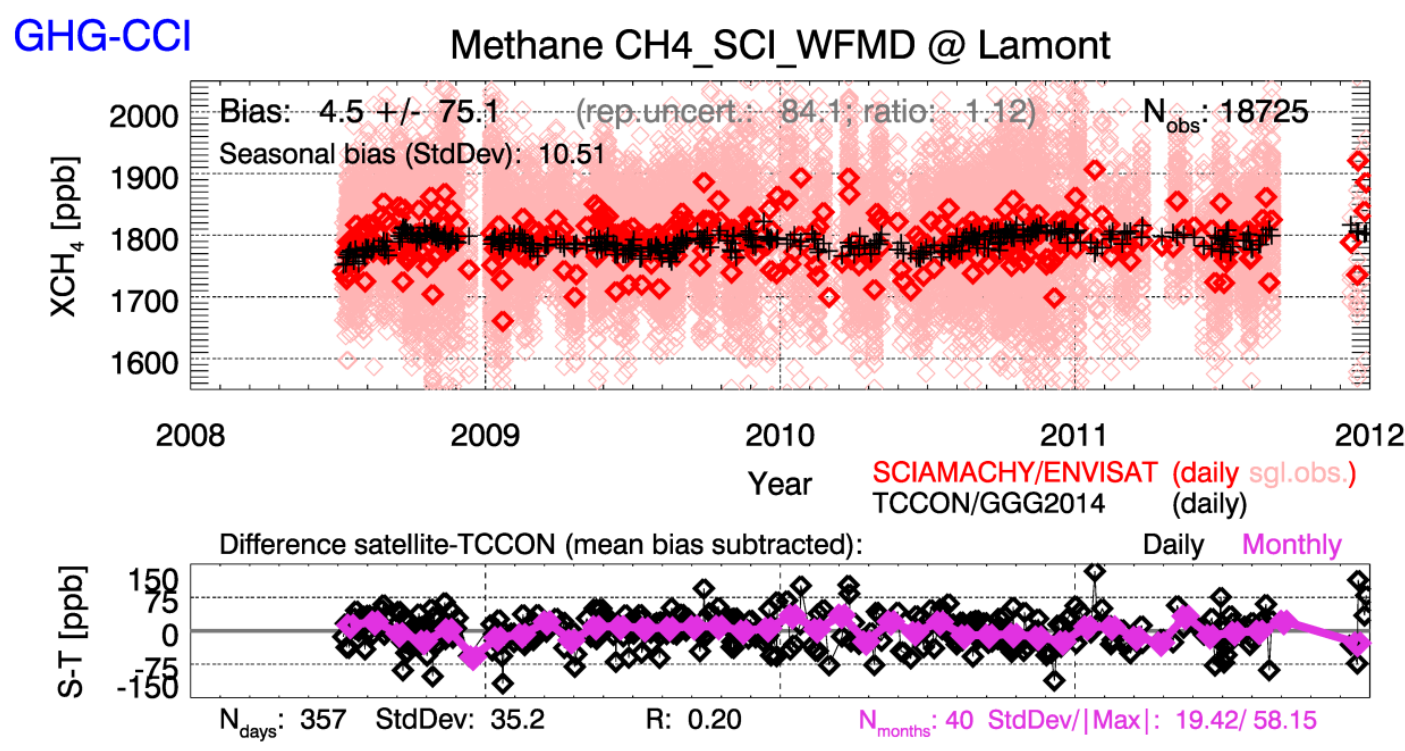

Figure 4: As Fig. 3 but for product CH4_SCI_WFMD.

As can be seen from Tab. 7, the (relative) biases are around 20 ppb for the SCIAMACHY products, which is worse than the required performance of better than $10 \mathrm{ppb}$. A much better performance in the range 6-7 ppb has been achieved for the GOSAT products (which, however, contain significantly less observations). The GOSAT products meet the GCOS and GHG-CCI URD systematic error

574 ("accuracy") requirements. requirement for random errors (better than $17 \mathrm{ppb}$ ) in contrast to the SCIAMACHY products which do 
not meet the threshold requirement. However one has to point out that the first years of

SCIAMACHY, where the data quality is much higher, is under-represented here as no TCCON observations are available during the first nearly two years of the ENVISAT mission (see Tab. 3).

Table 7: As Tab. 6 but for the GHG-CCI XCH${ }_{4}$ products. Note that the uncertainty of the TCCON reference data used to obtain the estimates listed here is about $4 \mathrm{ppb}$ (1-sigma).

\begin{tabular}{|c|c|c|c|c|c|}
\hline Product & $\begin{array}{c}\text { Systematic } \\
\text { error [ppb] } \\
\text { Regional, } \\
\text { seasonal } \\
\text { (combined) }\end{array}$ & $\begin{array}{l}\text { Uncertainty } \\
\text { (Random } \\
\text { error) [ppb] } \\
\text { (UncRat) }\end{array}$ & $\begin{array}{c}\text { Trend } \\
\text { (Stability) } \\
\text { [ppb/year] }\end{array}$ & $\begin{array}{l}\text { Offset } \\
\text { [ppb] }\end{array}$ & Nobs [-] \\
\hline CH4_SCI_WFMD & $11.3,16.8(20.3)$ & $81.6(1.0)$ & $2.0+/-4.3$ & -2.6 & 46958 \\
\hline CH4_SCI_IMAP & $14.8,14.4(20.7)$ & $48.3(1.3)$ & $4.5+/-2.8$ & -13.2 & 64841 \\
\hline CH4_GOS_OCPR & $4.6,3.4(5.7)$ & $11.9(1.0)$ & $0.0+/-1.1$ & 6.5 & 14639 \\
\hline CH4_GOS_SRPR & $3.4,5.1(6.1)$ & $12.8(0.9)$ & $-0.9+/-1.0$ & -2.6 & 13502 \\
\hline CH4_GOS_SRFP & $4.7,5.1(6.9)$ & $12.6(1.0)$ & $-1.0+/-1.3$ & -1.4 & 6819 \\
\hline CH4_GOS_OCFP & $4.1,5.7(7.0)$ & $13.4(0.7)$ & $-0.4+/-1.2$ & 0.7 & 5913 \\
\hline $\begin{array}{l}\text { Required } \\
\text { G / B / T }\end{array}$ & $\begin{array}{c}<10 \\
<1 / 5 / 10\end{array}$ & $\begin{array}{c}- \\
<9 / 17 / 34\end{array}$ & $\begin{array}{c}<2 \\
<1 / 5 / 10\end{array}$ & \multicolumn{2}{|r|}{$\begin{array}{l}\text { I URD } \\
\text { er et al., } \\
\text { b) }\end{array}$} \\
\hline
\end{tabular}

Table 7 also shows that the GOSAT products are very stable meeting the GCOS and (typically) even the GHG-CCI URD goal requirement. The SCIAMACHY products do not meet the GCOS stability requirement but apparently meet the GHG-CCI breakthrough requirement (of less than 5 ppb/year), at least concerning linear long-term drifts. However we also looked at shorter-term drifts of biases and 
identified issues in particular for the year 2010 and later years due to remaining issues from detector degradation (see Fig. 2).

\section{4. $\mathrm{XCO}_{2}$ comparisons with global models}

In the previous section we have presented validation results at selected TCCON sites. We have also performed detailed validation at a much larger number of TCCON sites as shown in Dils et al., 2016. Nevertheless, the number of ground-based validation sites is limited and large parts of the Earth are not covered (e.g., Africa, South America and large parts of Asia). Therefore, we present in this section detailed comparisons with global data sets (for recent comparisons with global models addressing different aspects see also Lindqvist et al., 2015, Parker et al., 2015, Kulawik et al., 2016). Here we use the output of the two global $\mathrm{CO}_{2}$ assimilation systems ("models") MACC (Chevallier et al., 2015), version 14r2, and CarbonTracker (Peters et al., 2007), version CT2013B. Note that comparisons with global models as well as $\mathrm{CO}_{2}$ flux inversion results using $\mathrm{CRDP} 3 \mathrm{XCO}_{2}\left(\right.$ and $\left.\mathrm{XCH}_{4}\right)$ are also presented and discussed in Chevallier et al., 2016.

\section{The European MACC (Monitoring of Atmospheric Composition Change) / CAMS (Copernicus} Atmospheric Monitoring System) project global atmospheric $\mathrm{CO}_{2}$ reanalysis data product, version v14r2, has been obtained from the MACC/CAMS website (http://macc.copernicus-

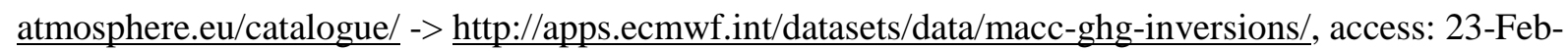
2016). The MACC Bayesian inversion method (e.g., Chevallier et al., 2015, and references given therein) is formulated in a variational way in order to estimate $\mathrm{CO}_{2}$ surface fluxes at relatively high resolution over the globe. Fluxes and mole fractions are linked in the system by the global atmospheric transport model of the Laboratoire de Météorologie Dynamique (LMDZ) with 39 layers in the vertical and with the same horizontal resolution than the inverted fluxes. LMDZ is nudged to ECMWFanalysed winds for flux inversion. The MACC inversion product also contains the 4-D $\mathrm{CO}_{2}$ field that is associated to the inverted surface fluxes through the LMDZ transport model. These 4-D fields have been used for this study. Satellite $\mathrm{XCO}_{2}$ observations have not been assimilated in MACCv14r2. 
619 The CarbonTracker atmospheric $\mathrm{CO}_{2}$ data product, version CT2013B, has been obtained from the

620 NOAA/ESRL CarbonTracker website (http://www.esrl.noaa.gov/gmd/ccgg/carbontracker/, access: 3-

621 Dec-2015) on which a detailed description of this version and how it has been generated is given. In

622 short, CarbonTracker, developed by the National Oceanic and Atmospheric Administration (NOAA)

623 Earth System Research Laboratory (ESRL), is an atmospheric $\mathrm{CO}_{2}$ inverse modeling system that

624 estimates optimized weekly surface $\mathrm{CO}_{2}$ flux using the Ensemble Kalman Filter (EnKF) technique.

625 Since the initial CarbonTracker release (Peters et al., 2007), a series of improvements have been made

626 with subsequent releases. These include increasing the sites from which $\mathrm{CO}_{2}$ data are assimilated,

627 increasing the resolution of atmospheric transport, improving the simulation of atmospheric

628 convection in the underlying transport model (TM5), and the use of multiple first-guess flux models to

629 estimate dependence on priors. These improvements are documented at http://carbontracker.noaa.gov.

630 CT2013B is a revision to the previous release (CT2013) and has the same time span, 2000-2012. For

631 CT2013B the atmospheric transport model has been significantly improved. CT2013B assimilates $\mathrm{CO}_{2}$

632 observations which are part of ESRL's new ObsPack data delivery system

633 (http://www.esrl.noaa.gov/gmd/ccgg/obspack/, Masarie et al., 2014). Satellite $\mathrm{XCO}_{2}$ observations have 634 not been assimilated in CT2013B.

636 In the following we show comparisons of three GHG-CCI $\mathrm{XCO}_{2}$ products with these two models in 637 order to find out if it is possible to identify which of the model data sets compares best with the 638 satellite data. The comparison has been done for the years 2010 and 2011 as these are the two years 639 where the SCIAMACHY and GOSAT time series overlap.

641 Figure 5a shows comparisons of the GHG-CCI satellite-derived $\mathrm{XCO}_{2}$ data products BESD, SRFP and 642 OCFP with the MACC and CarbonTracker (CT) model data sets for the time period June-August 643 (JJA) 2010 at a resolution of $2^{\circ} \times 2^{\circ}$. The model data have been sampled according to the time and 644 location of the (individual) satellite retrievals and the satellite averaging kernels have been applied to 645 the model data to consider the altitude sensitivity of the satellite retrievals when computing $\mathrm{XCO}_{2}$ 
from the model $\mathrm{CO}_{2}$ profiles (see Buchwitz et al., 2014). This has been done for each single satellite

sounding (ground pixel) and afterwards the model data and the satellite data have been averaged

The first row of Fig. 5a shows global maps of the three satellite data products. As can be seen, their spatial coverage differs. For example, the SCIAMACHY BESD data set is restricted to observations over land whereas the two GOSAT products also contain observations over oceans (corresponding to GOSAT sun-glint mode observations). As can also be seen, the spatial $\mathrm{XCO}_{2}$ pattern over land show similarities but also differences. For example, all three products show elevated $\mathrm{XCO}_{2}$ (red color) over similar parts of the western USA and Mexico, Amazonia and India and low $\mathrm{XCO}_{2}$ over parts of eastern Russia but different patterns over Africa, in particular northern Africa. These differences could be a result of the different sampling (different spatio-temporal coverage) of the satellite data products within the JJA time period (due to differences of the SCIAMACHY and GOSAT overpass time and the different quality filtering procedures of the different retrieval algorithms).

660

To investigate the effect of spatio-temporal sampling one can compare the satellite retrievals with the model data sets. The middle row of Fig. 5a shows the MACC model sampled as the three satellite data products (e.g., the left panel in the middle row entitled MACC@CO2_SCI_BESD is the MACC model sampled as the BESD product). MACC sampled as the three satellite products (middle row) also shows elevated $\mathrm{XCO}_{2}$ (red color) over similar parts of the western USA and Mexico, Amazonia and India in good to reasonable agreement with the satellite retrievals. Overall, all three MACC maps show similar $\mathrm{XCO}_{2}$ pattern indicating that the pattern does not depend significantly on the sampling of the satellite data products. Over northern Africa MACC and OCFP show quite similar pattern whereas SRFP $\mathrm{XCO}_{2}$ is significantly higher. There are nearly no BESD data over northern Africa as most of the BESD retrievals have been removed by the very strict BESD quality filter.

672 The bottom row of Fig. 5a shows CT sampled as the three satellite data products. Overall, there is good agreement between CT and MACC but there are also differences. For example, CT shows 
significantly lower $\mathrm{XCO}_{2}$ over large parts of eastern Russia compared to MACC. The satellite products show $\mathrm{XCO}_{2}$ values which are in between the values of MACC and CT but are significantly closer to MACC (see also Fig. 5b discussed below). This may indicate that over eastern Russia the CT $\mathrm{XCO}_{2}$ is somewhat too low during summer (JJA season; note that we get similar comparison results also for JJA 2011 not shown here).

Figure $5 \mathrm{~b}$ shows the differences between the models and the satellite data (first two rows) and the difference between the two models (bottom row). The bottom row shows that the largest difference between the two models is over large parts of eastern Russia with differences up to about $+4 \mathrm{ppm}$ (MACC higher than CT). For other regions the agreement is mostly in the range $+/-2 \mathrm{ppm}$ (green color). As can also be seen, the satellite data are in better agreement with MACC over eastern Russia.

685

To also consider the uncertainty of the satellite retrievals we have generated Fig. 5c. Our estimated uncertainties are shown in the bottom row of Fig. 5c. These uncertainties $\left(u n c_{t o t}\right)$ have been computed as follows:

$$
u n c_{t o t}(N)=\sqrt{\text { bias }_{\text {tot }}^{2}+\frac{r n d^{2}}{N}}
$$

Here $N$ are the number of satellite retrievals per $\left(2^{\circ} \times 2^{\circ}\right)$ grid cell, bias $s_{t o t}$ is the systematic error component of the total uncertainty (see Eq. (1) and Tab. 6) and $r n d$ is the random error component of the total uncertainty for single observations, which is assumed here to improve with $\sqrt{ } N$ when $N$ observations are averaged (see also Kulawik et al., 2016, and Sect. 5 for an assessment of how SCIAMACHY and GOSAT $\mathrm{XCO}_{2}$ uncertainties depend on the number of observations added). rnd has been computed by averaging the reported uncertainties of the $N \mathrm{XCO}_{2}$ retrievals located in each grid cell. Here the reported uncertainties of the CO2_GOS_OCFP product have been divided by 1.4 to compensate for the approximately $40 \%$ overestimation of the reported errors (see previous discussion of the results presented in Tab. 6). As can be seen from the bottom row of Fig. 5c, the uncertainty of the three satellite data products is typically around $1.2 \mathrm{ppm}$ (standard deviation $0.5 \mathrm{ppm}$ ). 
The first two rows displayed in Fig. 5c show the same model minus satellite differences as also shown

702

703

704

705

706

707

708

709

710

711

712

in Fig. $5 \mathrm{~b}$ but restricted to those $\left(2^{\circ} \times 2^{\circ}\right)$ grid cells where the (absolute value of the) difference is larger than the uncertainty shown in the bottom row, i.e., the first two rows only show cells with likely "significant differences". As can be seen, OCFP shows hardly any significant differences at least for extended regions (of connected cells). An exception is the already discussed part of eastern Russia, where differences are significant for CT (for all three satellite products) but not for MACC. Over parts of Amazonia MACC $\mathrm{XCO}_{2}$ is higher than BESD but this difference is much smaller for CT. Over parts of central Africa both models are higher than BESD. SRFP shows extended regions of differences over parts of northern Africa, Saudi Arabia and Iran (SRFP higher than the models as already mentioned when discussing Fig. 5a).

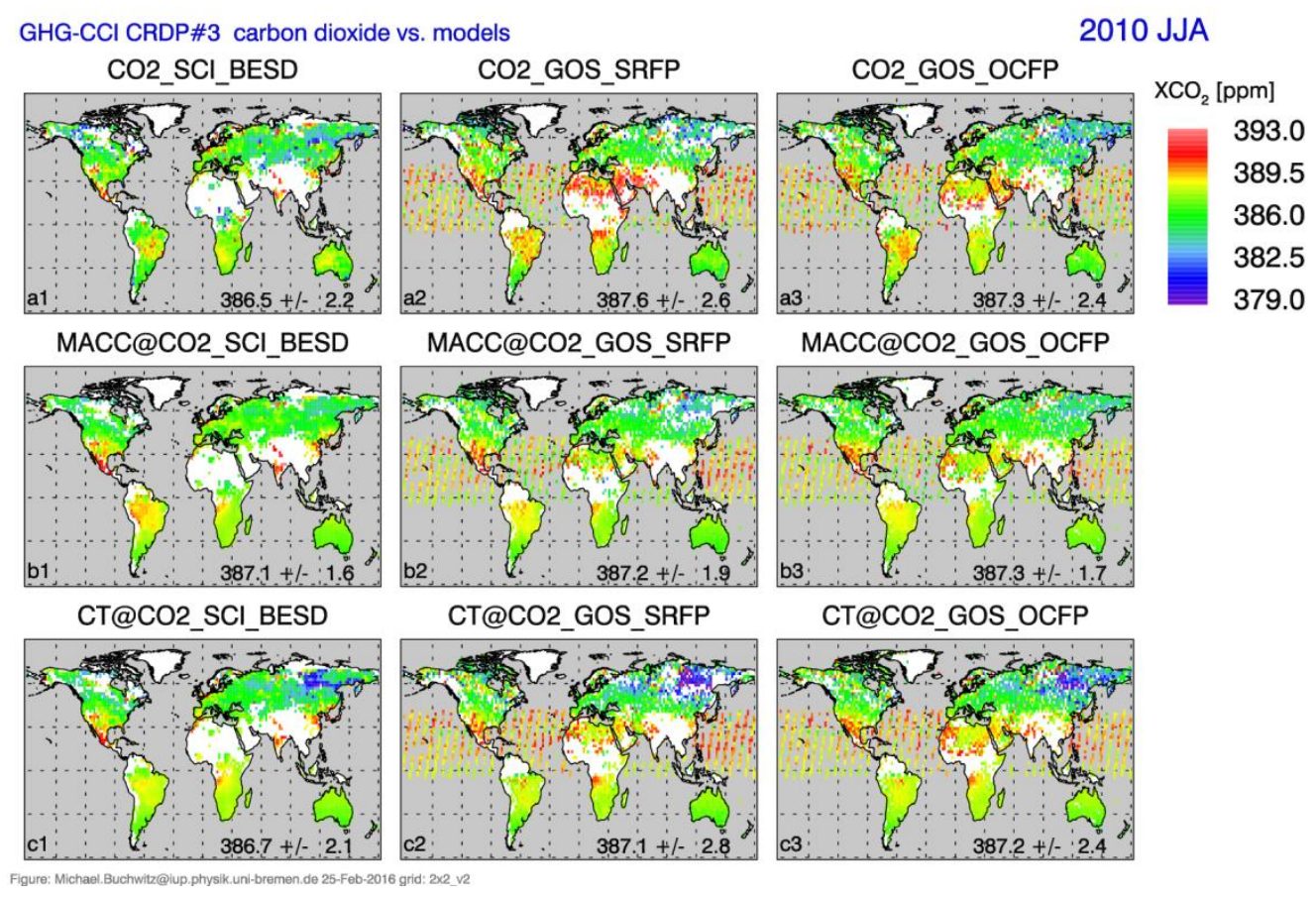

Figure 5a: Top: Satellite $\mathrm{XCO}_{2}$ gridded $2^{\circ} \mathrm{x} 2^{\circ}$ for June-August 2010 for the three products BESD

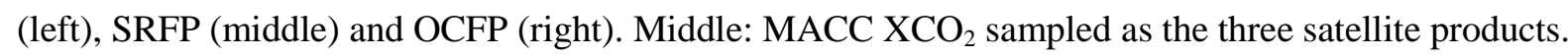
Bottom: CarbonTracker sampled as the satellite products. 

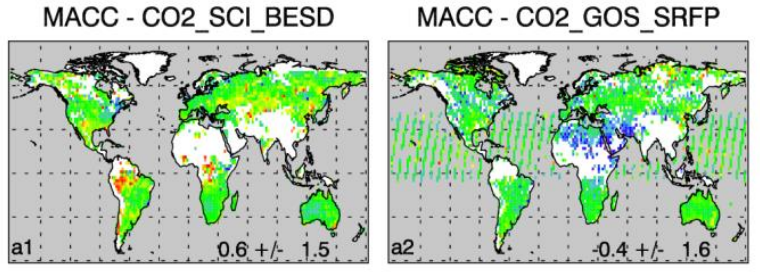

CT - CO2_SCI_BESD

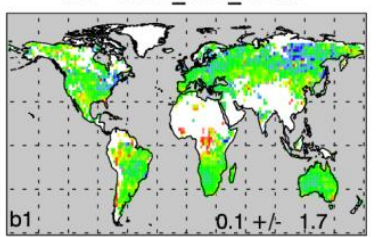

CT - CO2_GOS_SRFP

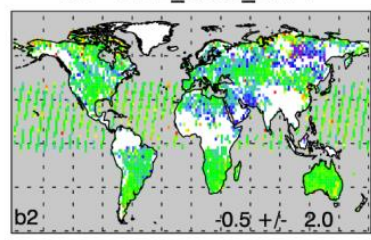

MACC - CT @ BESD

MACC - CT @ SRFP
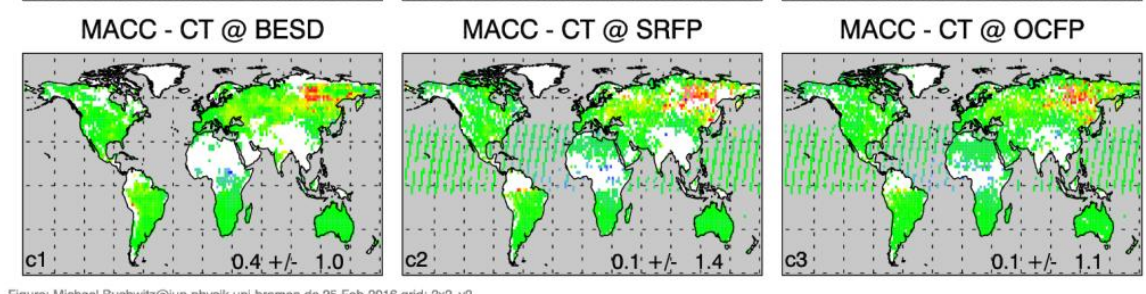

2010 JJA

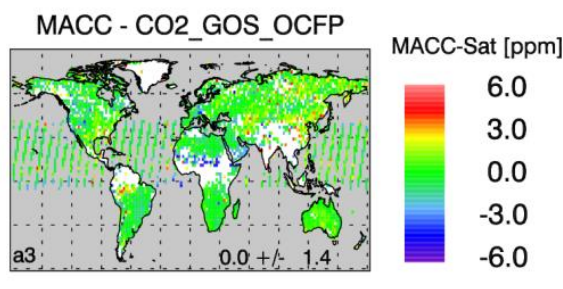

CT - CO2_GOS_OCFP

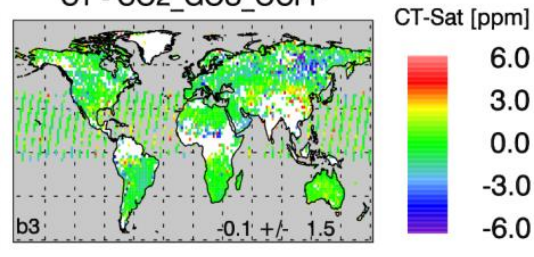

MACC-CT [ppm]

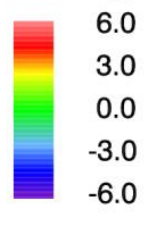

718 Figure 5b: As Fig. 5a but for the difference MACC-satellite (top), CarbonTracker-satellite (middle)

719 and MACC-CarbonTracker (bottom) sampled according to the three satellite products BESD (left),

SRFP (middle) and OCFP (right).
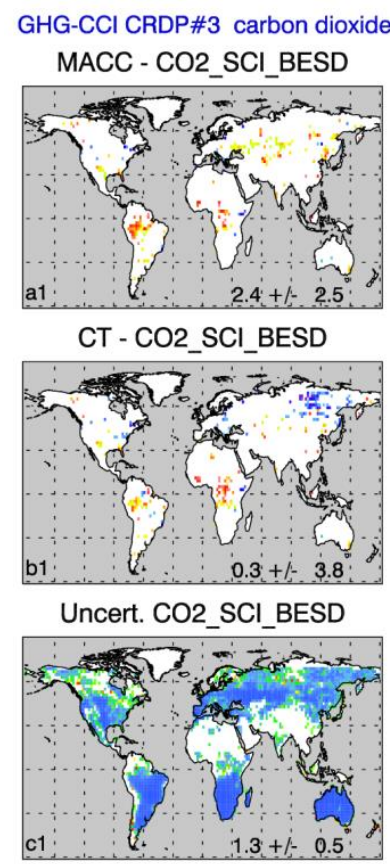

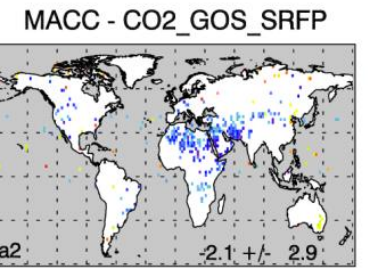

CT - CO2_GOS_SRFP
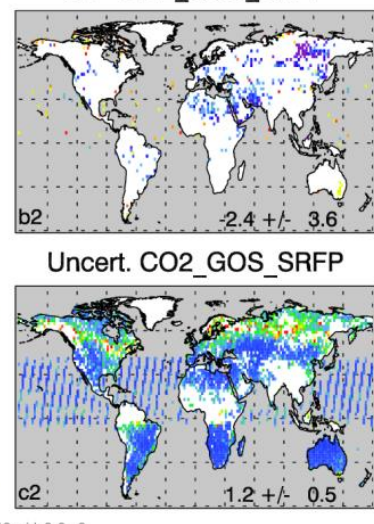

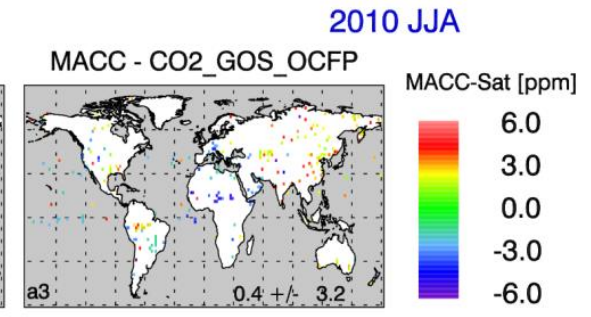

CT - CO2_GOS_OCFP
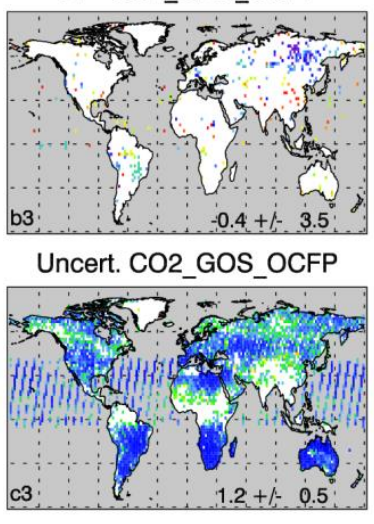

CT-Sat [ppm]

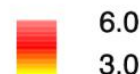

0.0

$-3.0$

$-6.0$

Uncert. [ppm]

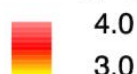

2.0

1.0

0.0

Figure 5c: As Fig. 5b but only for "significant" satellite-model differences (top and middle row) 
Figures $6 a-6 c$ show the same maps as Figs. $5 a-5 c$ but for the time period September - November 2011. Here the models show differences in particular over parts of Amazonia, southern Africa and India (Figs. 6a) of about 2-3 ppm (Figs. 6b, bottom). The "significant differences" between the models and the satellite retrievals are shown in Figs. 6c (top row for MACC; middle row for CT). Over Amazonia and parts of southern Africa MACC is higher than BESD over large regions, whereas CT shows less differences to BESD over Amazonia and hardly any differences over southern Africa. For southern Africa the differences between the models and BESD are similar as for OCFP. Over Africa both models are lower compared to SRFP. Over India both models, MACC and CT, are lower than SRFP and OCFP.
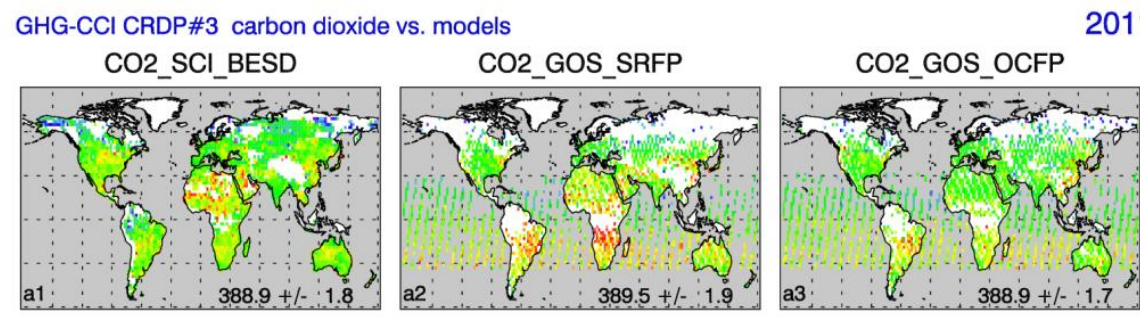

2011 SON
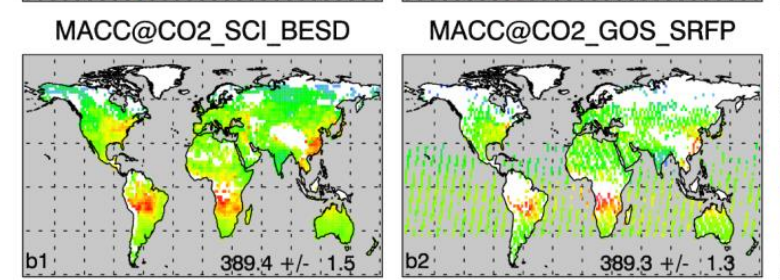

CT@CO2_SCI_BESD

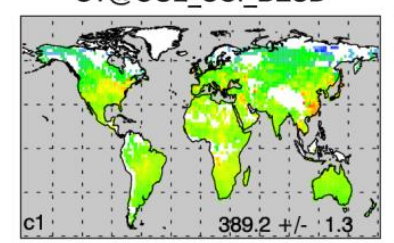

$$
\text { CT@CO2_GOS_SRFP }
$$
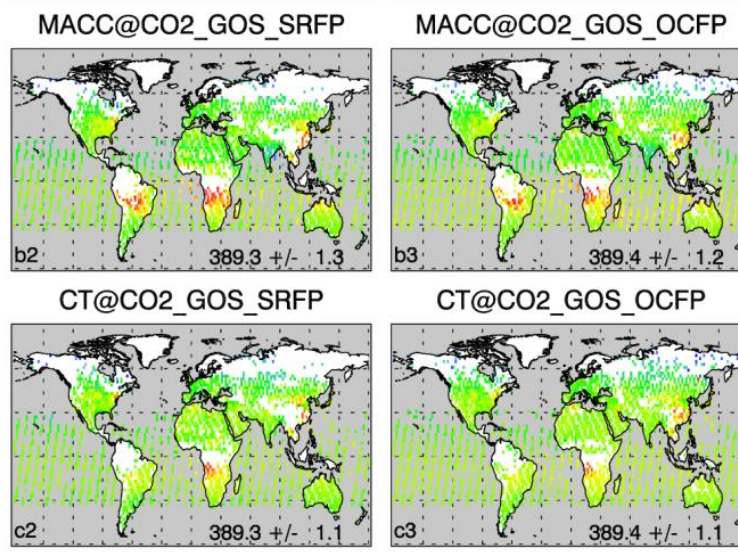
$\mathrm{XCO}_{2}$ [ppm]

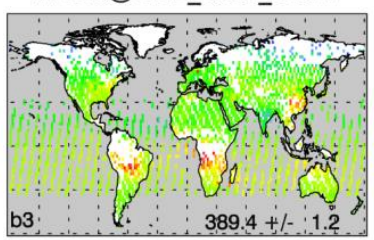

CT@CO2_GOS_OCFP

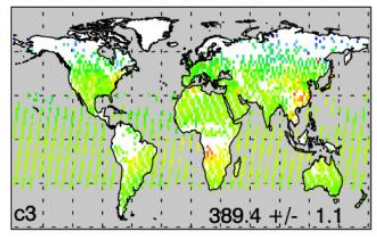

736 Figure 6a: As Fig. 5a but for September-November 2011. 


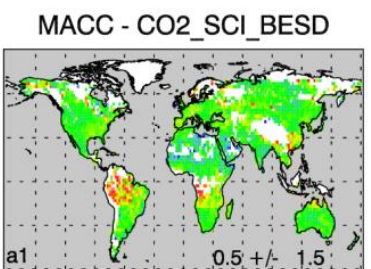

CT - CO2_SCI_BESD

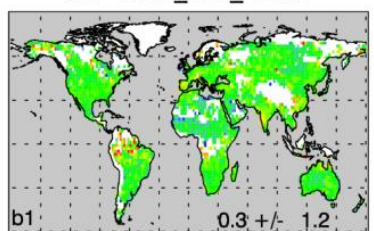

MACC - CT @ BESD

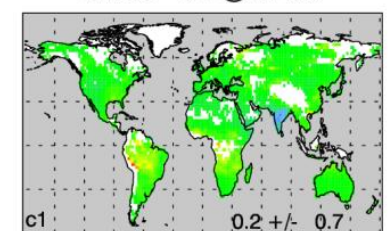

$02+1-0.7$

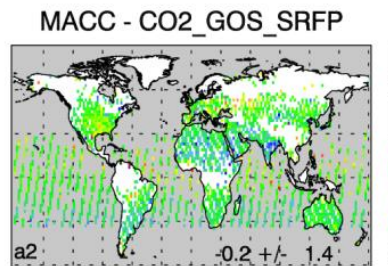

CT - CO2_GOS_SRFP

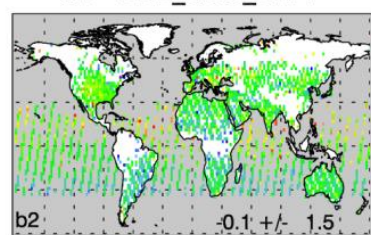

MACC - CT @ SRFP

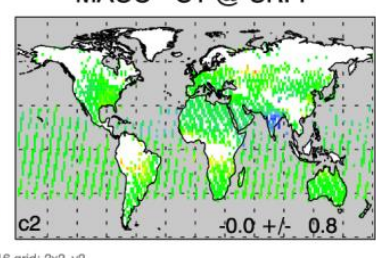

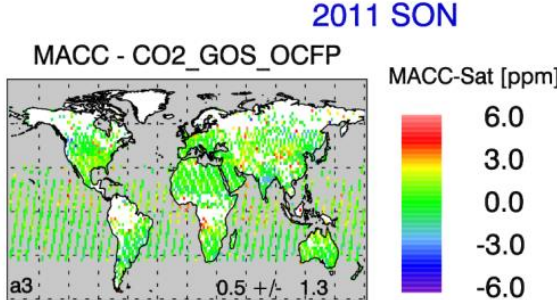

CT - CO2_GOS_OCFP

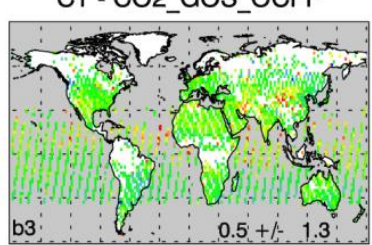

MACC - CT @ OCFP

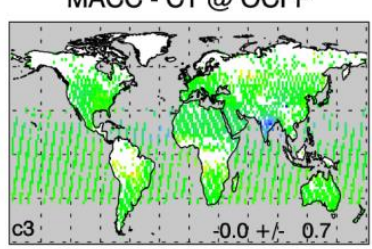

CT-Sat [ppm]

6.0

3.0

0.0

$-3.0$

$-6.0$

MACC-CT [ppm]

$\begin{array}{r}6.0 \\ 3.0 \\ 0.0 \\ -3.0 \\ -6.0 \\ \hline\end{array}$

740 Figure 6b: As Fig. 5b but for September-November 2011.

MACC - CO2_SCI_BESD

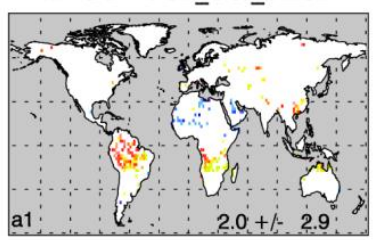

CT - CO2_SCl_BESD
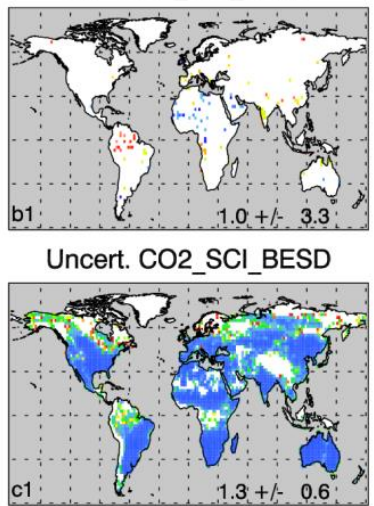

MACC - CO2_GOS_SRFP

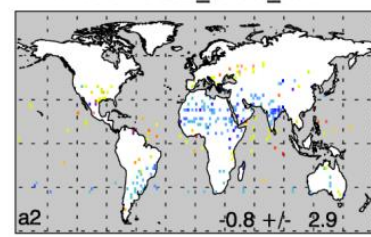

CT - CO2_GOS_SRFP
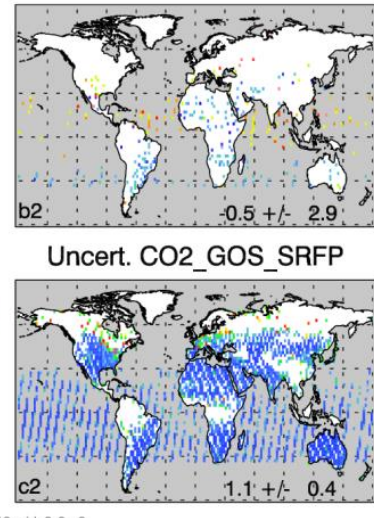

MACC - CO2_GOS_OCFP

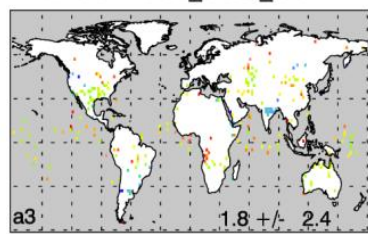

CT - CO2_GOS_OCFP

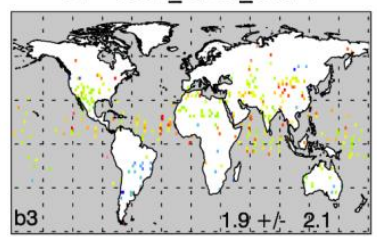

Uncert. CO2_GOS_OCFP

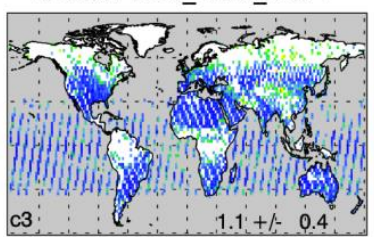

MACC-Sat [ppm]

6.0

3.0

0.0

$-3.0$

$-6.0$

CT-Sat [ppm]

6.0
3.0

0.0

$-3.0$

$-6.0$

Uncert. [ppm]

4.0
-3.0

2.0

1.0

0.0

743 Figure 6c: As Fig. 5c but for September-November 2011. 
To further investigate the agreements / disagreements between the $\mathrm{XCO}_{2}$ data sets we also generated time series. Figures 7 - 11 show time series of the satellite and model data sets for some of the discussed regions but also for other regions. Figure 7 shows time series for the region southern Africa (SAF) based on monthly averages. The top left panel shows BESD $\mathrm{XCO}_{2}$ (in red), MACC (black) and $\mathrm{CT}$ (grey) sampled as BESD. The panel on the right next to that panel shows the model - BESD differences as solid lines (in black for MACC and grey for CT) but also the estimated uncertainty (1sigma) of the satellite data (red vertical bars, one for each month). As can be seen, both models are higher by about $0.6 \mathrm{ppm}$ compared to BESD (top row), lower by about $0.7 \mathrm{ppm}$ compared to SRFP (middle), whereas the average difference is close to zero for OCFP. The standard deviation of the monthly differences is $0.5 \mathrm{ppm}$ for BESD for both models, for SRFP $0.3 \mathrm{ppm}$ relative to MACC and $0.5 \mathrm{ppm}$ relative to $\mathrm{CT}$, and for OCFP $0.5 \mathrm{ppm}$ relative to $\mathrm{MACC}$ and $0.6 \mathrm{ppm}$ relative to $\mathrm{CT}$. Note that typically the agreement between the models and the satellite retrievals is best where the number of satellite observations is highest (see $\mathrm{N}_{\mathrm{obs}}$ bars in light red). Overall, OCFP shows the best agreement with the two models with most of the differences within $1 \mathrm{ppm}$.

Figs. 8 - 11 also show time series as Fig. 7 but for the regions northern Africa (NAF, Fig. 8). North America (NAM, Fig. 9), Europe (EUR, Fig. 10) and China (CHI, Fig. 11). For region NAF (Fig. 8), BESD and OCFP agree with the models within typically $1 \mathrm{ppm}$ whereas SRFP has an apparent high with SRFP and OCFP within 1 ppm whereas the comparison with BESD shows somewhat larger

differences for some months. agreement is better for SRFP. For Europe (Fig. 10) the two models agree with each other but show typically a high bias compared to the satellite retrievals. For China (Fig. 11) the models typically agree 


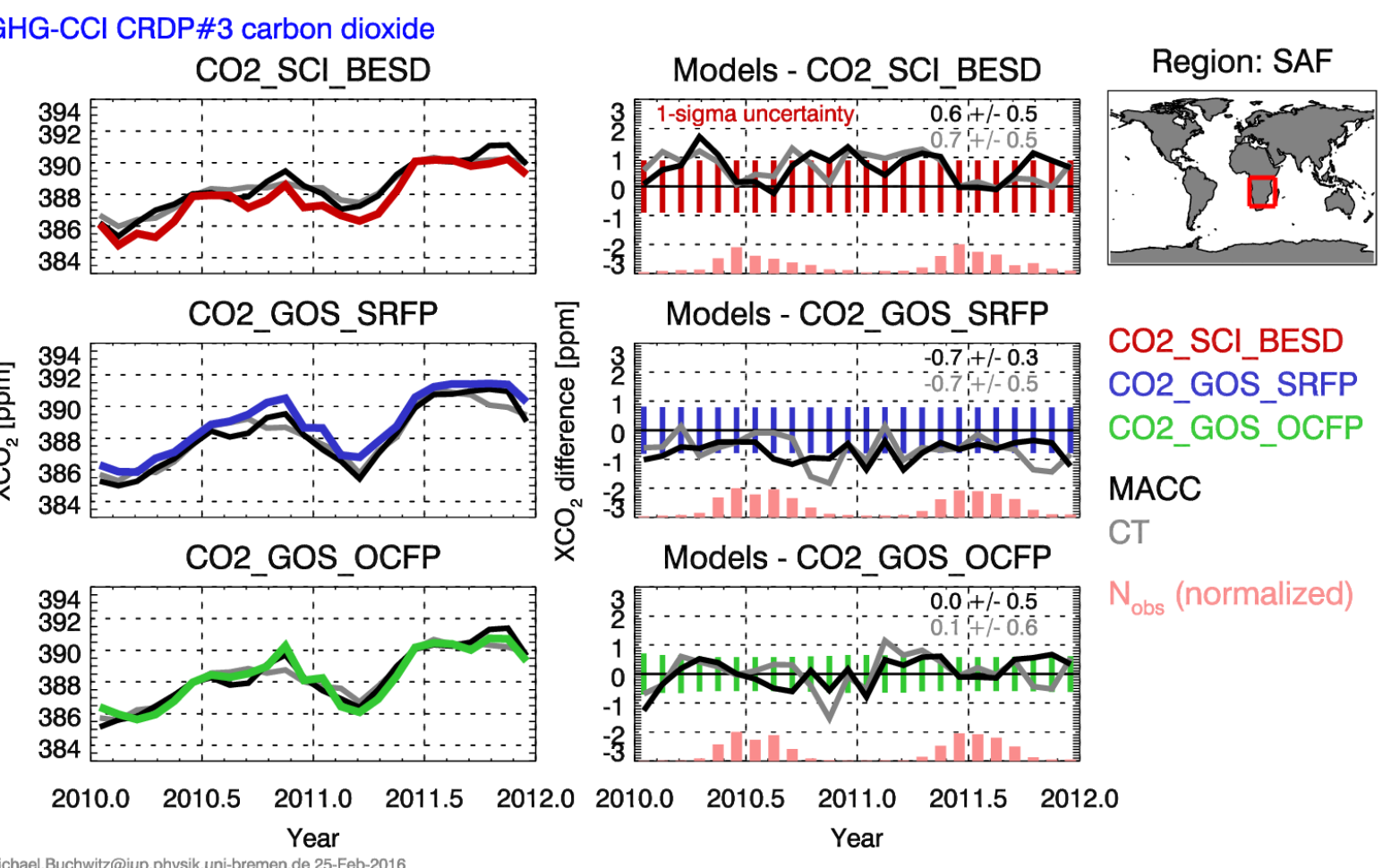

Region: SAF

CO2_SCl_BESD

CO2_GOS_SRFP

CO2_GOS_OCFP

MACC

(normalized)

773 Figure 7: Timeseries of satellite and model $\mathrm{XCO}_{2}$ for region Southern Africa (SAF; see map top

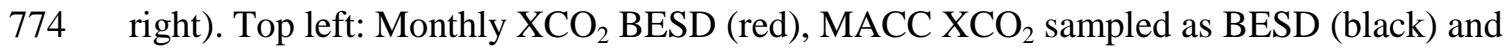

CarbonTracker $\mathrm{XCO}_{2}$ sampled as BESD (grey). Top middle: models - satellite for BESD: MACC-

776

777

778

779

780

781

782

783

784

785

BESD (black) and CarbonTracker-BESD (grey). The red vertical bars indicate the estimated

uncertainty of the satellite retrievals. In light red the number of satellite observations per month is shown (in arbitrary units). Middle: as top row but for SRFP (blue), Bottom: as top and middle row but for OCFP (green). Listed on top right in each panel on the right hand side is mean $+/$ - standard deviation of the difference between the models and the satellite $\mathrm{XCO}_{2}$.

Overall it can be concluded that the models agree with the satellite retrievals within typically $1-2 \mathrm{ppm}$ but depending on region and time period differences can also be somewhat larger. As shown in Kulawik et al., 2016, MACC and CT fit TCCON typically quite well but TCCON stations are usually in place where there are surface air sample measurements to constrain the models (see also Parker et al., 2015). Differences may therefore be larger elsewhere. Nevertheless, we found that the two model data sets are very similar, in particular when averaged over large region (see regional timeseries). 
However, we also identified significant differences between them. For example, CT shows

Russia during summer 2010 (JJA season) (also during JJA 2011, but this has not been shown here).

Over parts of Amazonia and southern Africa during autumn 2011 (SON season) MACC is about 2

793 here). We also identified significant differences between the satellite data products, e.g., a high or a

794 low bias of SRFP compared to the other two satellite products BESD and OCFP depending on region 795 and time period.

796

GHG-CCI CRDP\#3 carbon dioxide
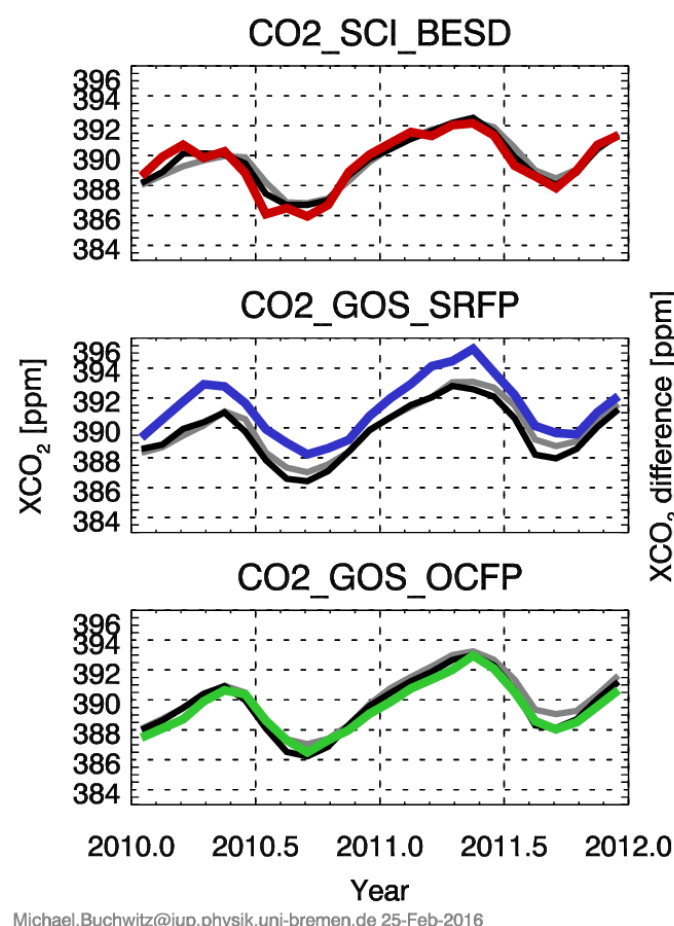
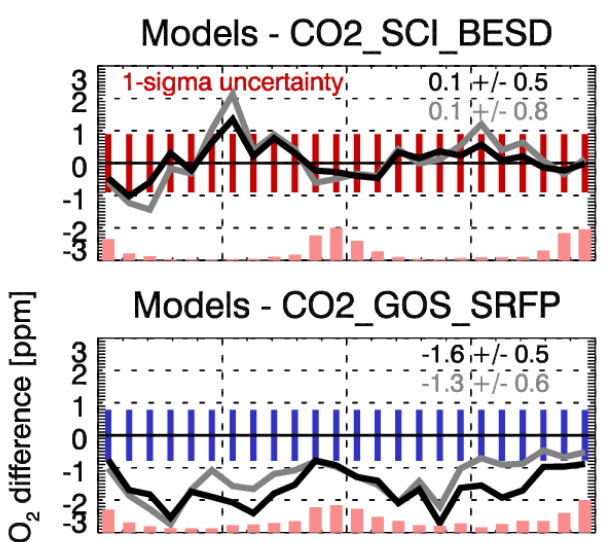

$\times$

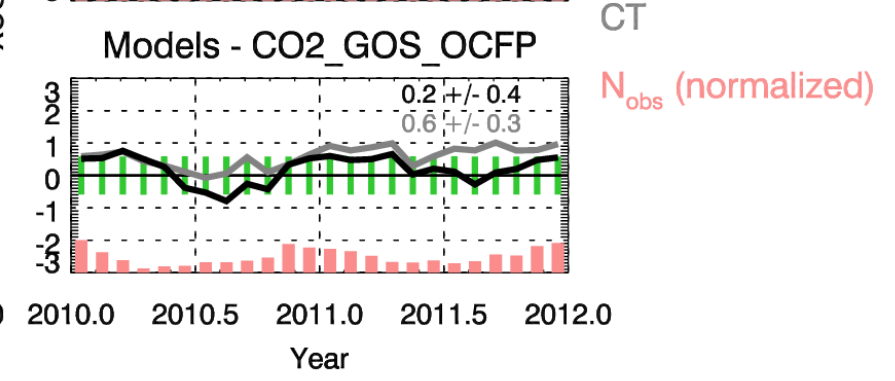

Region: NAF

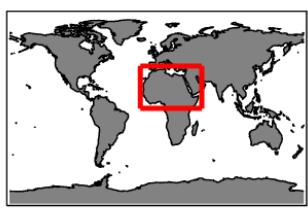

CO2_SCl_BESD

CO2_GOS_SRFP

CO2_GOS_OCFP

MACC

CT
CT
797

$798 \quad$ Figure 8: As Fig. 7 but for region Northern Africa (NAF). 
GHG-CCI CRDP\#3 carbon dioxide
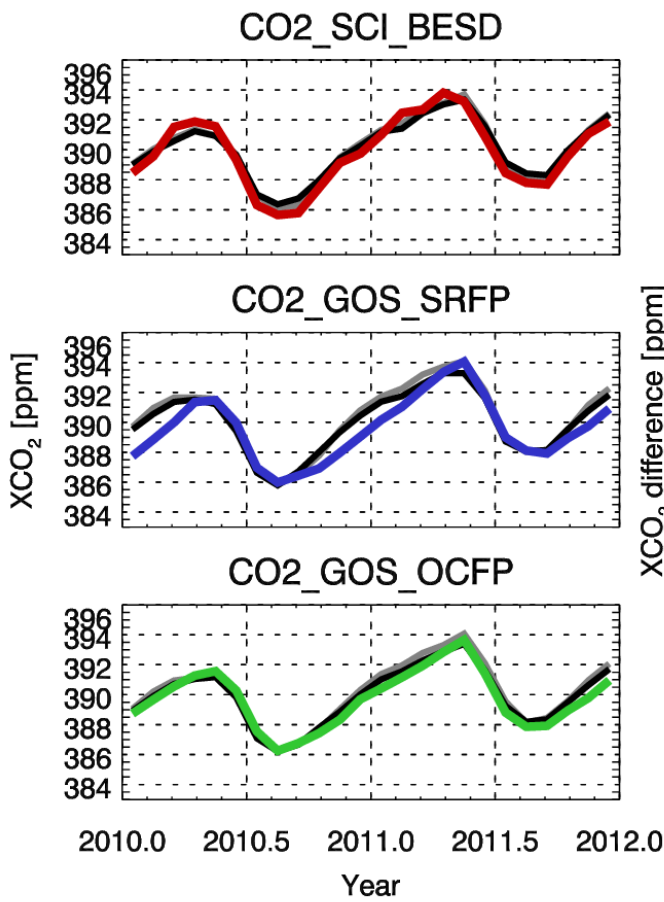

Michael.Buchwitz@iup.physik.uni-bremen.de 25-Feb-2016
Models - CO2_SCI_BESD

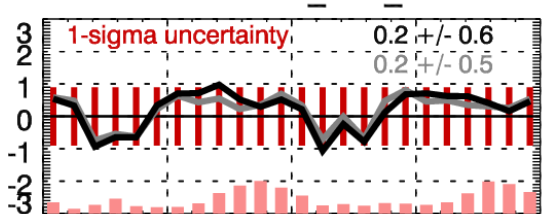

Models - CO2_GOS_SRFP

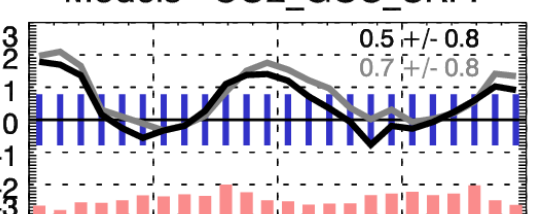

Models - CO2_GOS_OCFP

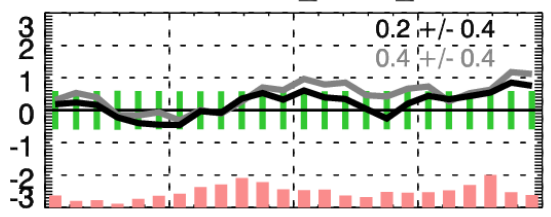

$2010.0 \quad 2010.5 \quad 2011.0 \quad 2011.5 \quad 2012.0$
Region: NAM

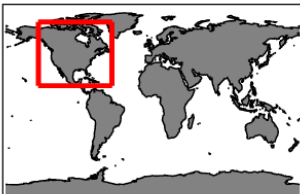

CO2_SCl_BESD

CO2_GOS_SRFP

CO2 GOS OCFP

MACC

CT

(normalized)

802

Figure 9: As Fig. 7 but for region North America (NAM).

804

GHG-CCI CRDP\#3 carbon dioxide
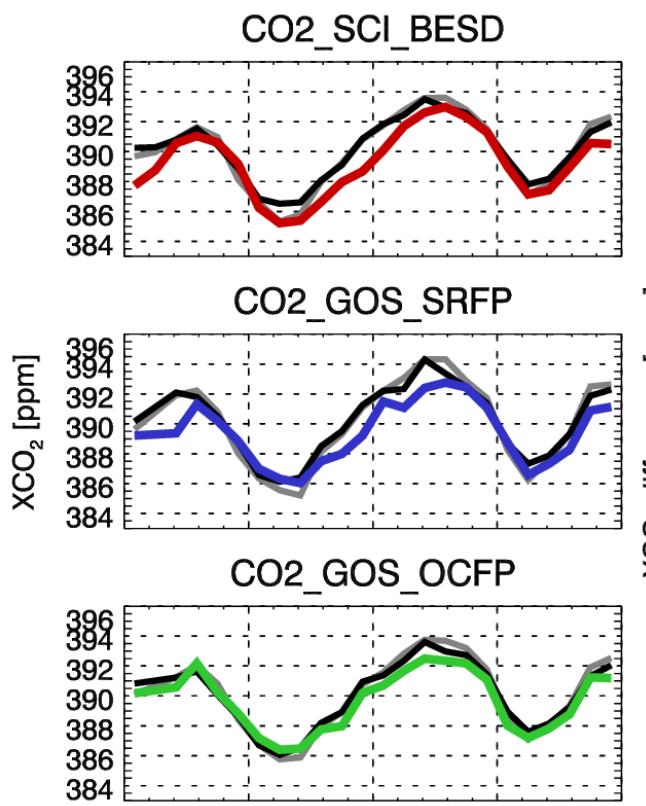

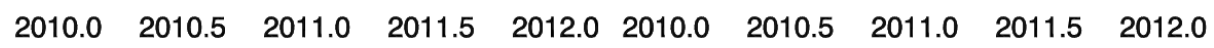

805

Michael.Buchwitz@iup.physik.uni-bremen.de 25-Feb-2016

Figure 10: As Fig. 7 but for region Europe (EUR).

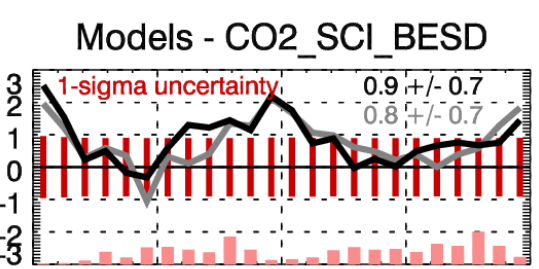

Region: EUR

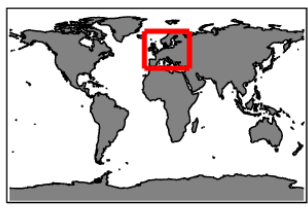

CO2_SCl_BESD CO2_GOS_SRFP CO2_GOS_OCFP MACC $\mathcal{O}^{\mathrm{x}}$

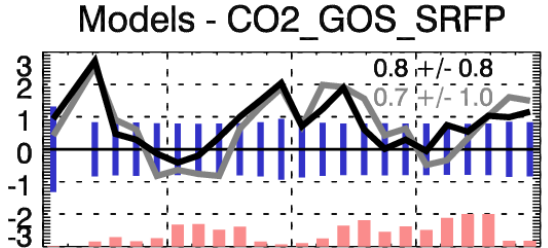

Models - CO2_GOS_OCFP

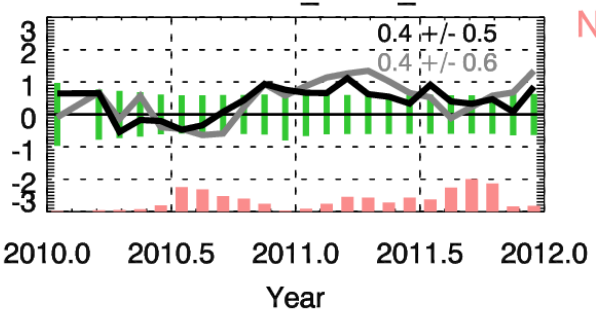

(normalized) 
CO2_SCl_BESD
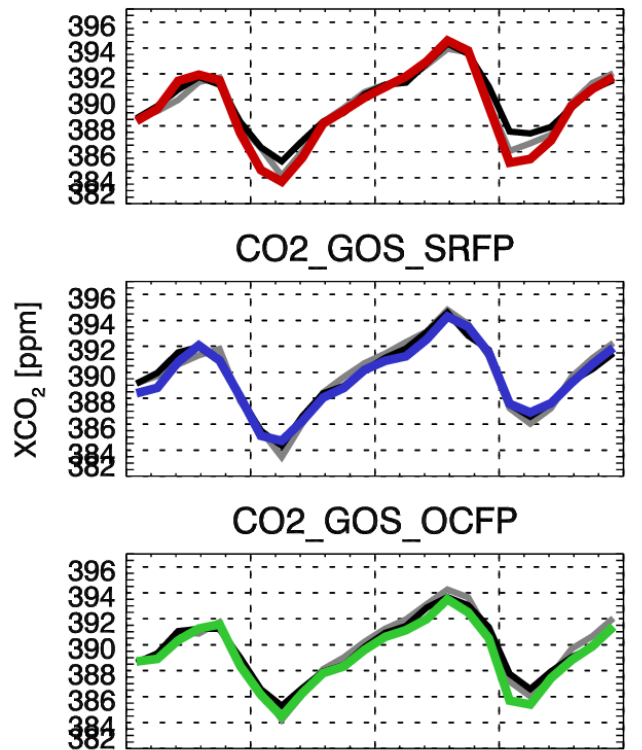

$2010.0 \quad 2010.5 \quad 2011.0 \quad 2011.5 \quad 2012$

Year
Models - CO2_SCI_BESD

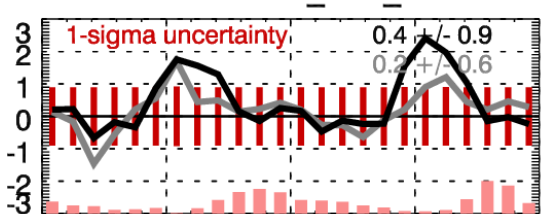

$\bar{E} \quad$ Models - CO2_GOS_SRFP

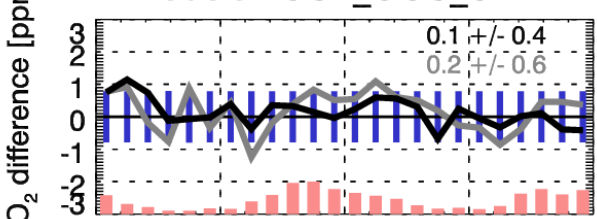

X्र
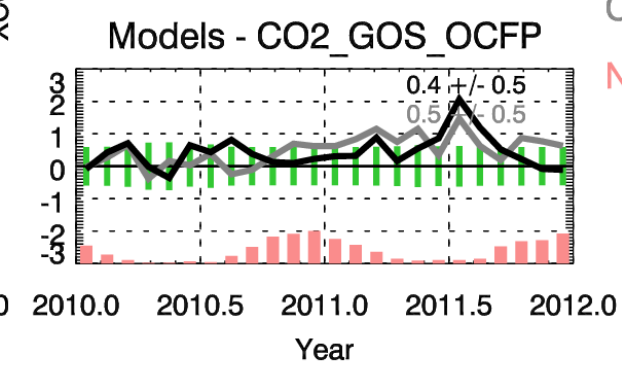

Region: $\mathrm{CHI}$

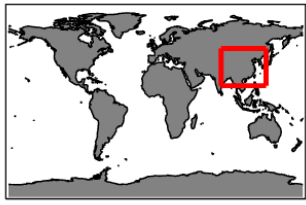

CO2_SCl_BESD

CO2_GOS_SRFP

CO2 GOS OCFP

MACC

CT

(normalized)

Michael.Buchwitz@iup.physik.uni-bremen.de 25-Feb-2016

810 Figure 11: As Fig. 7 but for region China (CHI).

\section{5. $\mathrm{XCO}_{2}$ error correlations}

814 The GHG-CCI ECA products are Level 2 products, i.e., product information such as $\mathrm{XCO}_{2}$ and its uncertainty is reported for each individual satellite ground pixel. For applications such as inverse modelling also information on spatio-temporal error correlations would be highly beneficial (see Chevallier et al., 2014b). However, it is not trivial because the needed co-located ground truth

818 observations are only available at TCCON sites, which makes it difficult to obtain reliable global

819 statistics representative for all temporal and spatial distances. Additionally, error correlations may

820 systematically differ depending on surface reflectivity, atmospheric composition (e.g., aerosols and

821 cirrus), viewing geometry and solar illumination conditions. This would violate the assumption of stationarity made by our approach. 
Here we report on an attempt to obtain spatio-temporal error correlations in a form useful for inverse modelling and related applications such as CCDAS (Carbon Cycle Data Assimilation Systems (e.g., Kaminski et al., 2013)) (for alternative attempts see Chevallier et al., 2013, and Kulawik et al., 2016). The goal is to obtain a covariance matrix, where each diagonal element corresponds to the variance of the retrieved $\mathrm{XCO}_{2}$ of a corresponding ground pixel, which is the square of the reported $\mathrm{XCO}_{2}$ uncertainty, and each non-diagonal element corresponds to the co-variance between two retrievals, i.e., different ground pixels. Our method to estimate co-variances is based on semivariogram analysis (Montero et al., 2015) of the satellite minus TCCON XCO 2 differences. As shown in Reuter et al., 2016, where the analysis method is described in detail, we have used two different parameterizations resulting in a "full" and an "approximate" error covariance matrix. The full error covariance matrix (not shown here; see Reuter et al., 2016, for details) is dense and does not necessarily vanish even for long distances. Therefore, it may be computationally too expensive for many users. A simpler parametrization of the error covariance, whose use can be computationally less demanding, is given by the following formula ("exponential product model"):

$$
C_{i j}=\frac{\sigma_{i} \sigma_{j}}{V_{\max }}\left\{\begin{array}{r}
k e^{-\left(\Delta s / l_{s}+\Delta t / l_{t}\right),} \Delta s>0 \text { or } \Delta l>0 \\
V_{\max }, \Delta s=0 \text { and } \Delta l=0
\end{array}\right.
$$

Here, $\sigma_{i}$ and $\sigma_{j}$ correspond to the reported uncertainties for ground pixels $i$ and $j$ and $\Delta s$ and $\Delta t$ are their corresponding spatial (in $\mathrm{km}$ ) and temporal (in days) differences, respectively. These uncertainties $\sigma$ are related to the uncertainties reported in the BESDv02.01.01 product files, $\tilde{\sigma}$, by $\sigma=\tilde{\sigma} * 0.2741+$ $1.3294 \mathrm{ppm} . V_{\max }, k, l_{s}$ and $l_{t}$ are parameters obtained via model semivariogram least squares fitting. Parameter $V_{\max }$ (in semivariogram analyses often called "sill", see, e.g., the textbook of Montero et al., 2015) corresponds to the error variance due to all error components. Parameter $k$ is the variance due to correlated errors. The difference $V_{\max }-k$ (in semivariogram analyses often called "nugget", see, e.g., the textbook of Montero et al., 2015) corresponds to the fully uncorrelated part of the error, e.g., due to instrumental noise. Parameter $l_{s}$ is the spatial correlation length and $l_{t}$ is the temporal correlation length. As shown in Reuter et al., 2016, the following values have been obtained for the 
CO2_SCI_BESD product: $V_{\max }=3.80+/-0.05 \mathrm{ppm}^{2} ; k=1.16+/-0.27 \mathrm{ppm}^{2} ; l_{s}=1476+/-633 \mathrm{~km}$ and

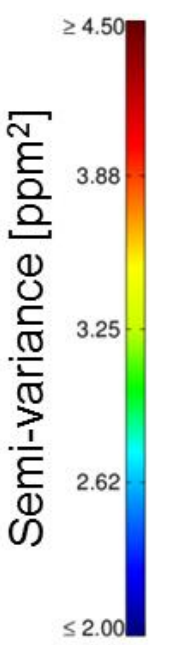
$l_{t}=58+/-20$ days (see Fig. 12). Equation 3 and its corresponding parameters has been derived based on relatively coarse assumptions (see Reuter et al., 2016, for details) and future analysis may result in a better approximation but for now we recommend that users who would like to or have to take error correlations into account use the results presented here.

Figure 12: Modelled semivariogram (left; with the four fit parameters listed top right) and corresponding correlogram (right) for product CO2_SCI_BESD. The correlogram, $\rho$, has been obtained from the semivariogram, $\gamma$, via $\rho=1-\gamma / V_{\max }$. The covariance matrix, $C$ (see Eq. (3)), and the correlogram, $\rho$, are related by $\rho=C / V_{\max }$.

\section{6. $\mathrm{XCH}_{4}$ global maps and time series}

864

Finally we present some comparisons of global maps of $\mathrm{XCH}_{4}$ ECA products (Figs. 13a-13d). Note that many detailed figures for each month and each product (including number of observations per grid cell, standard deviation, etc.) and latitude-resolved time series for the CRDP3 products are shown on the GHG-CCI website (see $\mathrm{XCH}_{4}\left(\right.$ and $\mathrm{XCO}_{2}$ ) CRDP3 "browse images" on http://www.esa-ghg- 
cci.org/) and detailed assessment results are presented in several technical documents (e.g., Buchwitz et al., 2016).

Figure 13a shows a global composite map of product CH4_SCI_WFMD for the years 2003-2004, i.e., for the first two years of the GHG-CCI ECA time series at $2^{\circ} \times 2^{\circ}$ resolution. A major feature is the north-south methane gradient, with higher concentrations over the northern hemisphere, where most of the methane sources are located. Clearly visible by higher regional $\mathrm{XCH}_{4}$ values are major methane source regions such as China (wetland and rice paddy emissions). However, we have to point out that it is not trivial (if not impossible) to draw clear conclusions with respect to regional emissions from maps such as those shown in Fig 13a due to temporal sampling issues (depending on month, the satellite data may be quite sparse) combined with atmospheric transport and the long lifetime of $\mathrm{CH}_{4}$ in the atmosphere. For example, large values over water (Fig. 13a) are typically not due to local sources but due to outflow from major source regions (e.g., Asia) located on land.

Figure 13b shows the corresponding map for product CH4_SCI_IMAP. As can be seen, this product is limited to observations over land. The spatial $\mathrm{XCH}_{4}$ pattern is similar compared to WFMD (Fig. 13a) but not identical. This is due to differences in spatio-temporal sampling of the satellite data, different random errors (see Tab. 7), differences in altitude sensitivity but also due to (different) biases in the satellite data products.

Figures 13c and 13d show global maps for the two GOSAT products CH4_GOS_SRFP (Fig. 13c) and CH4_SCI_OCPR (Fig. 13d) for 2013-2014, i.e., for the two last years of the CRDP3 ECA data set. Both products show similar (but not identical) coverage and pattern, for similar reasons as explained above for the two SCIAMACHY products. Note that detailed comparison and assessment results are shown in Buchwitz et al., 2016, and other technical documents available on the GHG-CCI website (http://www.esa-ghg-cci.org/) and we recommend that users interested in these data products take the information given in these documents into account when using our data products for any given application. 
(a)
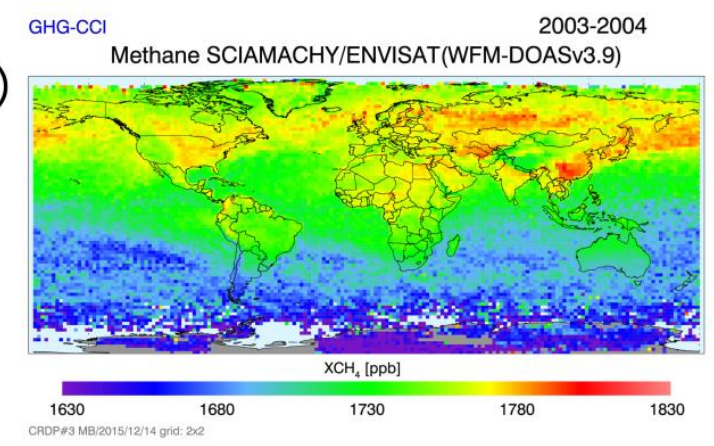

GHG-CCI Methane TANSO/GOSAT(SRFPv2.3.7)

(c)

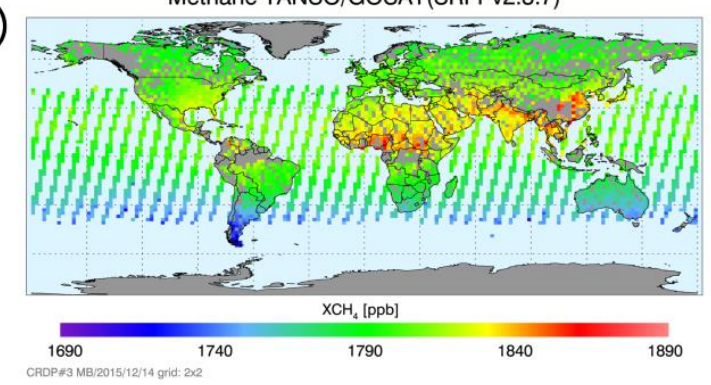

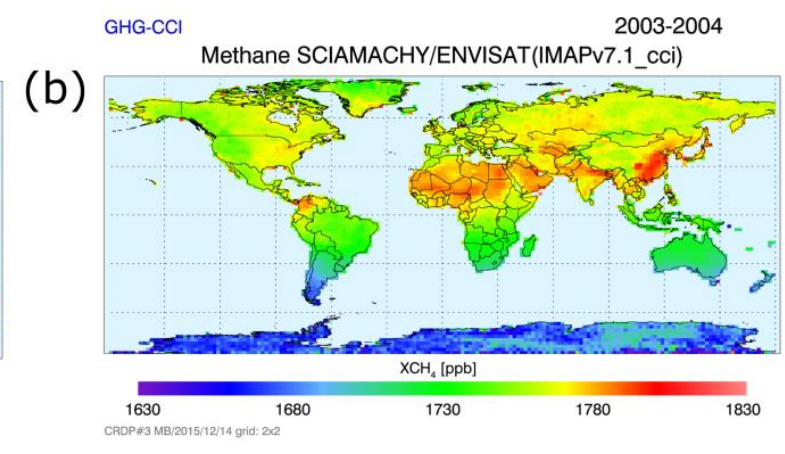

(d)

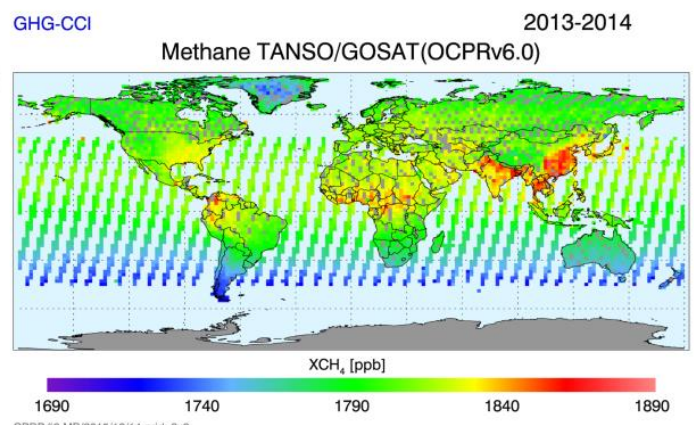

900 Figure 13: Global maps of satellite-derived $\mathrm{XCH}_{4}$. (a) Global map of product CH4_SCI_WFMD

901 obtained by gridding all individual retrievals during 2003-2004 using $2^{\circ} \times 2^{\circ}$ grid cells. (b) As (a) but

902 for product CH4_SCI_IMAP. (c) As (a) but for CH4_GOS_SRFP during 2013-2014. (d) As (c) but for

903 CH4_GOS_OCPR. Note the change of the color scale (+ $60 \mathrm{ppb}$ ) for the 2013-2014 maps, i.e., for (c)

904 and (d).

905

\section{Summary and conclusions}

$\mathrm{CO}_{2}$ and $\mathrm{CH}_{4}$ are the two most important greenhouse gases emitted by mankind and responsible for a large fraction of the observed global warming. Despite their importance our knowledge on their

909 various variable surface sources and sinks has significant gaps. Satellite observations of atmospheric

$910 \mathrm{CO}_{2}$ and $\mathrm{CH}_{4}$ are increasingly being used to help closing relevant knowledge gaps. We have presented

911 a short overview based on peer-reviewed publications to demonstrate the progress which has been

912 made in recent years concerning the use of satellite retrievals of near-surface-sensitive column-

913 averaged dry air mole fractions of $\mathrm{CO}_{2}$ and $\mathrm{CH}_{4}$, i.e., $\mathrm{XCO}_{2}$ and $\mathrm{XCH}_{4}$. Nevertheless, much more still 
914 needs to be learned about the sources and sinks of these greenhouse gases but this requires additional

915 efforts in terms of further improving the quality of the satellite retrievals, to extend their time series

916 (using existing and future sensors) and to further improve transport modelling and inversion methods

917 as well as more and better satellite and non-satellite observations (e.g., Ciais et al., 2014).

918

919 Here we have presented a new $\mathrm{XCO}_{2}$ and $\mathrm{XCH}_{4}$ satellite-derived data set called "Climate Research

920 Data Package" No. 3 (CRDP3) which has been generated within the ESA CCI project GHG-CCI. The

921 data products are available for all interested users from the website of this project (http://www.esa-

922 ghg-cci.org/).

923

924 The presented $\mathrm{XCO}_{2}$ and $\mathrm{XCH}_{4}$ data sets cover the time period end of $2002-2014$ and have been

925 derived from the nadir near-infrared / shortwave-infrared (NIR/SWIR) radiance observations of the

926 two satellite instruments SCIAMACHY/ENVISAT (2002 - 2012) and TANSO/GOSAT (launched

927 2009). We have presented time series and global maps including comparisons with TCCON (Wunch

928 et al., 2010, 2011) ground-based observations (version GGG2014) and global $\mathrm{CO}_{2}$ assimilation system

929 ("models") data sets (European MACC/CAMS model (v14r2) (Chevallier et al., 2015) and NOAA's

930 CarbonTracker (version CT2013B) (Peters et al., 2007)).

931

932 Based on validation using TCCON data at six sites we have shown that with one exception the satellite

$933 \mathrm{XCO}_{2}$ products have (relative) systematic errors of less than $1 \mathrm{ppm}$, i.e., they meet the Global Climate

934 Observing System (GCOS) accuracy requirement. All $\mathrm{XCO}_{2}$ products are very stable showing no

935 significant long-term linear trend and they meet the GCOS stability requirement of better than 0.2

$936 \mathrm{ppm} / \mathrm{year}$.

937

938 The GOSAT $\mathrm{XCH}_{4}$ retrievals also meet the GCOS accuracy requirement of better than $10 \mathrm{ppb}$ and are

939 even close to meeting the GHG-CCI breakthrough requirement of better than $5 \mathrm{ppb}$. These products

940 are also very stable showing no significant long-term linear trend and they meet the GCOS stability

941 requirement of better than $2 \mathrm{ppb} /$ year. For the SCIAMACHY $\mathrm{XCH}_{4}$ products the situation is more 
complex due to detector degradation. In particular for 2010 and later years this results in significant biases (not meeting the GCOS accuracy requirement of better than $10 \mathrm{ppb}$ ) and large scatter.

\section{The SCIAMACHY BESD $\mathrm{XCO}_{2}$ and the two GOSAT $\mathrm{XCO}_{2}$ products (SRON/KIT's SRFP}

("RemoTeC") product and University of Leicester's OCFP product) have been compared with output from the MACC model and NOAA's CarbonTracker (CT). Detailed comparison results are presented in terms of global maps and time series for selected regions. Overall it can be concluded that the $\mathrm{CO}_{2}$ models agree with the satellite retrievals within typically 1-2 ppm but depending on region and time period differences can also be somewhat larger. The two model data sets are very similar, in particular when averaged over large regions, but we also identified significant differences between them. For example, $\mathrm{CT}$ shows significantly lower $\mathrm{XCO}_{2}$ compared to MACC (approximately 4 ppm) over large parts of eastern Russia during summer (JJA season) with MACC being in better agreement with the satellite data compared to CT. Over parts of Amazonia and southern Africa during autumn (SON season) MACC is about $2 \mathrm{ppm}$ higher than CT and over India MACC is about 2-3 ppm lower. For India the satellite data are in better agreement with CT compared to MACC but for Amazonia and southern Africa the situation is less clear. We also identified significant differences between the satellite data products, e.g., a high or a low bias of SRFP compared to other satellite products depending on region and time period. Because the link between atmospheric concentrations and surface fluxes is typically complex our analysis does not necessarily permit to draw clear conclusions on which satellite data set gives the most reliable surface fluxes when used in an inverse modelling framework. This underlines the importance of using multiple satellite products and inversion methods in order to draw robust conclusions on GHG sources and sinks as aimed at in several recent publications (e.g., Chevallier et al., 2013, 2016; Reuter et al., 2014a; Houweling et al., 2015; Feng et al., 2016).

Furthermore, we have presented an attempt to provide users with information on spatio-temporal error correlations using a parameterization of an error covariance matrix obtained via semivariogram analysis of satellite minus TCCON $\mathrm{XCO}_{2}$ differences. We have also presented global $\mathrm{XCH}_{4}$ maps to 
970 illustrate how the various new $\mathrm{XCH}_{4}$ products "look like". Finally, we would like to point out that

971 additional information in terms of various technical documents and separate figures is available on the

972 website of the GHG-CCI project (http://www.esa-ghg-cci.org/) (please note in particular the link to

973 “CRDP (Data)”).

974

975

Acknowledgements

976

977

This study has been funded by ESA via the GHG-CCI project of ESA's Climate Change Initiative

978

(CCI). We thank ESA/DLR for providing us with SCIAMACHY Level 1 data products and JAXA for

979

GOSAT Level 1B data. We also thank ESA for making these GOSAT products available via the ESA

980

Third Party Mission archive. We also thank the TCCON team (in particular P. Wennberg, CalTech)

981

for providing TCCON data (obtained via http://tccon.ornl.gov), the European MACC/CAMS projects

982

for providing $\mathrm{CO}_{2}$ model fields (obtained from http://macc.copernicus-atmosphere.eu/) and

983

NOAA/ESRL for providing CarbonTracker data (obtained via

984

http://www.esrl.noaa.gov/gmd/ccgg/carbontracker/).

985

986

1. References

987

Alexe, M., Bergamaschi, P., Segers, A., et al. (2015), Inverse modeling of $\mathrm{CH}_{4}$ emissions for 20102011 using different satellite retrieval products from GOSAT and SCIAMACHY, Atmos.

989 Chem. Phys., 15, 113-133, www.atmos-chem-phys.net/15/113/2015/, doi:10.5194/acp-15-

990 113-2015.

991

Basu, S., Guerlet, S., Butz, A., et al. (2013), Global $\mathrm{CO}_{2}$ fluxes estimated from GOSAT retrievals of 992 total column $\mathrm{CO}_{2}$, Atmos. Chem. Phys., 13, 8695-8717.

Basu, S., Krol, M., Butz, A., et al. (2014), The seasonal variation of the $\mathrm{CO}_{2}$ flux over Tropical Asia estimated from GOSAT, CONTRAIL and IASI, Geophys. Res. Lett., doi:

995 10.1002/2013GL059105. 
Bergamaschi, P., Frankenberg, C., Meirink, J.F., Krol, M., Dentener, F., Wagner, T., Platt, U., Kaplan, J.O., Körner, S., Heimann, M., Dlugokencky, E.J., Goede, A. (2007), Satellite chartography of atmospheric methane from SCIAMACHY onboard ENVISAT: 2. Evaluation based on inverse model simulations, J. Geophys. Res., 112, D02304, doi:10.1029/2006JD007268.

Bergamaschi, P., Frankenberg, C., Meirink, J. F., Krol, M., Villani, M. G., Houweling, S., Dentener, F., Dlugokencky, E. J., Miller, J. B., Gatti, L. V., Engel, A., Levin, I. (2009), Inverse modeling of global and regional $\mathrm{CH}_{4}$ emissions using SCIAMACHY satellite retrievals, J. Geophys. Res., 114, D22301, doi:10.1029/2009JD01228.

Bergamaschi, P., Houweling, H., Segers, A., et al. (2013), Atmospheric $\mathrm{CH}_{4}$ in the first decade of the 21 st century: Inverse modeling analysis using SCIAMACHY satellite retrievals and NOAA surface measurements, J. Geophys. Res., 118, 7350-7369, doi:10.1002/jrgd.5048.

Bösch, H., Baker, D., Connor, B., Crisp, D., and Miller, C. (2011), Global Characterization of $\mathrm{CO}_{2}$ Column Retrievals from Shortwave-Infrared Satellite Observations of the Orbiting Carbon Observatory-2 Mission, Radio Sci., 3, 270-304, doi:10.3390/rs3020270.

Bloom, A. A., Palmer, P. I., Fraser, A., Reay, D. S., Frankenberg, C. (2010), Large-scale controls of methanogenesis inferred from methane and gravity spaceborne data, Science, 327, 322-325, doi:10.1126/science.1175176.

Bovensmann, H., Burrows, J. P., Buchwitz, M., Frerick, J., Noël, S., Rozanov, V. V., Chance, K. V., Goede, A. H. P. (1999), SCIAMACHY - Mission objectives and measurement modes, $J$. Atmos. Sci., 56 (2), 127-150.

Bovensmann, H., M. Buchwitz, J. P. Burrows, M. Reuter, T. Krings, K. Gerilowski, O. Schneising, J. Heymann, A. Tretner, and J. Erzinger (2010), A remote sensing technique for global monitoring of power plant $\mathrm{CO}_{2}$ emissions from space and related applications, Atmos. Meas. Tech., 3, 781-811. 
Buchwitz, M., V.V. Rozanov, and J.P. Burrows (2000), A near-infrared optimized DOAS method for the fast global retrieval of atmospheric $\mathrm{CH}_{4}, \mathrm{CO}, \mathrm{CO}_{2}, \mathrm{H}_{2} \mathrm{O}$, and $\mathrm{N}_{2} \mathrm{O}$ total column amounts from SCIAMACHY Envisat-1 nadir radiances, J. Geophys. Res. 105, 15,231-15,245.

Buchwitz, M., de Beek, R., Burrows, J. P., Bovensmann, H., Warneke, T., Notholt, J., Meirink, J. F., Goede, A. P. H., Bergamaschi, P., Körner, S., Heimann, M., Schulz, A. (2005), Atmospheric methane and carbon dioxide from SCIAMACHY satellite data: Initial comparison with chemistry and transport models, Atmos. Chem. Phys., 5, 941-962.

Buchwitz, M., Schneising, O., Burrows, J. P., Bovensmann, H., Reuter, M., Notholt, J. (2007), First direct observation of the atmospheric $\mathrm{CO}_{2}$ year-to-year increase from space, Atmos. Chem. Phys., 7, 4249-4256.

Buchwitz, M., M. Reuter, H. Bovensmann, D. Pillai, J. Heymann, O. Schneising, V. Rozanov, T. Krings, J. P. Burrows, H. Boesch, C. Gerbig, Y. Meijer, and A. Loescher (2013), Carbon Monitoring Satellite (CarbonSat): assessment of atmospheric $\mathrm{CO}_{2}$ and $\mathrm{CH}_{4}$ retrieval errors by error parameterization, Atmos. Meas. Tech., 6, 3477-3500.

Buchwitz, M., Detmers, R., Boesch, H., et al. (2014), Product Specification Document for the GHGCCI project of ESA’s Climate Change Initiative, version 3 (PSDv3), 6. June 2014, (link: http://www.esa-ghg-cci.org/index.php?q=webfm_send/160).

Buchwitz, M., M. Reuter, O. Schneising, H. Boesch, S. Guerlet, B. Dils, I. Aben, R. Armante, P. Bergamaschi, T. Blumenstock, H. Bovensmann, D. Brunner, B. Buchmann, J. P. Burrows, A. Butz, A. Chédin, F. Chevallier, C. D. Crevoisier, N. M. Deutscher, C. Frankenberg, F. Hase, O. P. Hasekamp, J. Heymann, T. Kaminski, A. Laeng, G. Lichtenberg, M. De Mazière, S. Noël, J. Notholt, J. Orphal, C. Popp, R. Parker, M. Scholze, R. Sussmann, G. P. Stiller, T. Warneke, C. Zehner, A. Bril, D. Crisp, D. W. T. Griffith, A. Kuze, C. O’Dell, S. Oshchepkov, V. Sherlock, H. Suto, P. Wennberg, D. Wunch, T. Yokota, Y. Yoshida (2015), The Greenhouse Gas Climate Change Initiative (GHG-CCI): comparison and quality assessment of 
near-surface-sensitive satellite-derived $\mathrm{CO}_{2}$ and $\mathrm{CH}_{4}$ global data sets, Remote Sensing of Environment, 162, 344-362, doi:10.1016/j.rse.2013.04.024.

Buchwitz, M., Dils, B., Boesch, H., Crevoisier, C., Detmers, D., Frankenberg, C., Hasekamp, O., Hewson, W., Laeng, A., Noël, S., Notholt, J., Parker, R., Reuter, M., Schneising, O. (2016), ESA Climate Change Initiative (CCI) Product Validation and Intercomparison Report (PVIR) for the Essential Climate Variable (ECV) Greenhouse Gases (GHG) for data set Climate Research Data Package No. 3 (CRDP\#3), Version 4.0, 24. Feb. 2016 (link: http://www.esaghg-cci.org/?q=webfm_send/300).

Burrows, J. P., Hölzle, E., Goede, A. P. H., Visser, H., and Fricke, W. (1995), SCIAMACHYScanning Imaging Absorption Spectrometer for Atmospheric Chartography, Acta Astronaut., 35(7), 445-451, doi:10.1016/0094-5765(94)00278-t.

Butz, A., Hasekamp, O.P., Frankenberg, C., Vidot, J., Aben, I. (2010), $\mathrm{CH}_{4}$ retrievals from spacebased solar backscatter measurements: Performance evaluation against simulated aerosol and cirrus loaded scenes, J. Geophys. Res., VOL. 115, D24302, doi:10.1029/2010JD014514.

Butz, A., Guerlet, S., Hasekamp, O., Schepers, D., Galli, A., Aben, I., Frankenberg, C., Hartmann, J.M., Tran, H., Kuze, A., Keppel-Aleks, G., Toon, G., Wunch, D., Wennberg, P., Deutscher, N., Griffith, D., Macatangay, R. , Messerschmidt, J., Notholt, J. , Warneke, T. (2011), Towards accurate $\mathrm{CO}_{2}$ and $\mathrm{CH}_{4}$ observations from GOSAT, Geophys. Res. Lett., Geophys. Res. Lett., doi:10.1029/2011GL047888.

Butz, A., Galli, A., Hasekamp, O., Landgraf, J., Tol, P., Aben, I. (2012), Remote Sensing of Environment, TROPOMI aboard Sentinel-5 Precursor : Prospective performance of $\mathrm{CH}_{4}$ retrievals for aerosol and cirrus loaded atmospheres, 120, 267-276, doi:10.1016/j.rse.2011.05.030.

Canadell, J. G., Ciais, P., Dhakal, S., Dolman, H., Friedlingstein, P., Gurney. K. R,, Held, A., Jackson, R. B., Le Quéré, C., Malone, E. L., Ojima, D. S., Patwardhan, A., Peters, G. P., Raupach, M. 
R. (2010), Interactions of the carbon cycle, human activity, and the climate system: a research portfolio, Current Opinion in Environmental Sustainability, 2, 301-311.

Chevallier, F., Feng, L., Bösch, H., Palmer, P. I., Rayner, P. J. (2010), On the impact of transport model errors for the estimation of $\mathrm{CO}_{2}$ surface fluxes from GOSAT observations, Geophys. Res. Lett., 37, L21803, doi:10.1029/2010GL044652.

Chevallier, F., and O'Dell, C. W. (2013), Error statistics of Bayesian $\mathrm{CO}_{2}$ flux inversion schemes as seen from GOSAT, Geophys. Res. Lett., doi: 10.1002/grl.50228.

Chevallier, F., Palmer, P.I., Feng, L., Boesch, H., O'Dell, C.W., Bousquet, P. (2014a), Towards robust and consistent regional $\mathrm{CO}_{2}$ flux estimates from in situ and space-borne measurements of atmospheric $\mathrm{CO}_{2}$, Geophys. Res. Lett., 41, 1065-1070, DOI: 10.1002/2013GL058772.

Chevallier, F., Buchwitz, M., Bergamaschi, et al. (2014b), User Requirements Document for the GHG-CCI project of ESA's Climate Change Initiative, version 2 (URDv2), 28. August 2014, (link: http://www.esa-ghg-cci.org/?q=webfm send/173).

Chevallier, F. (2015), On the statistical optimality of $\mathrm{CO}_{2}$ atmospheric inversions assimilating $\mathrm{CO}_{2}$ column retrievals, Atmos. Chem. Phys., 15, 11133-11145.

Chevallier, F., M. Alexe, P. Bergamaschi, D. Brunner, L. Feng, S. Houweling, T. Kaminski, W. Knorr, T. T. van Leeuwen, J. Marshall, P. I. Palmer, M. Scholze, A.-M. Sundström, M. Voßbeck (2016), ESA Climate Change Initiative (CCI) Climate Assessment Report (CAR) for Climate Research Data Package No. 3 (CRDP\#3) of the Essential Climate Variable (ECV) Greenhouse Gases (GHG), Version 3, pp. 94, 3 May 2016 (link: http://www.esa-ghgcci.org/?q=webfm_send/318 ).

Ciais, P., Dolman, A. J., Bombelli, A., et al. (2014), Current systematic carbon cycle observations and needs for implementing a policy-relevant carbon observing system, Biogeosciences, 11, 35473602, www.biogeosciences.net/11/3547/2014/, doi:10.5194/bg-11-3547-2014.

Cogan, A. J., Boesch, H., Parker, R. J., et al. (2012), Atmospheric carbon dioxide retrieved from the Greenhouse gases Observing SATellite (GOSAT): Comparison with ground-based TCCON 
observations and GEOS-Chem model calculations, J. Geophys. Res., 117, D21301, doi:10.1029/2012JD018087.

Cressot, C., F. Chevallier, P. Bousquet, et al. (2014), On the consistency between global and regional methane emissions inferred from SCIAMACHY, TANSO-FTS, IASI and surface measurements, Atmos. Chem. Phys., 14, 577-592.

Crevoisier, C., Chédin, A., Matsueda, H., Machida, T., Armante, R., Scott, N. A. (2009a), First year of upper tropospheric integrated content of $\mathrm{CO}_{2}$ from IASI hyperspectral infrared observations, Atmos. Chem. Phys., 9, 4797-4810.

Crevoisier, C., Nobileau, D., Fiore, A., Armante, R., Chédin, A., Scott, N. A. (2009b), Tropospheric methane in the tropics - first year from IASI hyperspectral infrared observations, Atmos. Chem. Phys., 9, 6337-6350.

Crevoisier, C., D. Nobileau, R. Armante, L. Crépeau, T. Machida, Y. Sawa, H. Matsueda, T. Schuck, T. Thonat, J. Pernin, N. A. Scott, and A. Chédin (2013), The 2007-2011 evolution of tropical methane in the mid-troposphere as seen from space by MetOp-A/IASI, Atmos. Chem. Phys., $13,4279-4289$.

Crisp, D., Atlas, R. M., Bréon, F.-M., Brown, L. R., Burrows, J. P., Ciais, P., Connor, B. J., Doney, S. C., Fung, I. Y., Jacob, D. J., Miller, C. E., O’Brien, D., Pawson, S., Randerson, J. T., Rayner, P., Salawitch, R. J., Sander, S. P., Sen, B., Stephens, G. L., Tans, P. P., Toon, G. C., Wennberg, P. O., Wofsy, S. C., Yung, Y. L., Kuang, Z., Chudasama, B., Sprague, G., Weiss, B., Pollock, R., Kenyon, D., and Schroll, S. (2004), The Orbiting Carbon Observatory (OCO) mission, Adv. Space Res., 34, 700-709, doi:10.1016/j.asr.2003.08.062.

Crisp, D., Fisher, B. M., O’Dell, C., Frankenberg, C., Basilio, R., Boesch, H. L. R. Brown, R. Castano, B. Connor, N. M. Deutscher, A. Eldering, D. Griffith, M. Gunson, A. Kuze, L. Mandrake, J. McDuffie, J. Messerschmidt, C. E. Miller, I. Morino, V. Natraj, J. Notholt, D. M. O’Brien, F. Oyafuso, I. Polonsky, J. Robinson, R. Salawitch, V. Sherlock, M. Smyth, H. Suto, T. E. Taylor, D. R. Thompson, P. O.Wennberg, D.Wunch, Y. L. Yung (2012), The ACOS $\mathrm{CO}_{2}$ 
retrieval algorithm - Part II: Global $\mathrm{XCO}_{2}$ data characterization, Atmos. Meas. Tech., 5, 687707.

Deng, F., Jones, D. B. A., Henze, D. K., Bousserez, N., Bowman, K. W., Fisher, J. B., Nassar, R., O'Dell, C., Wunch, D., Wennberg, P. O., Kort, E. A., Wofsy, S. C., Blumenstock, T., Deutscher, N. M., Griffith, D. W. T., Hase, F., Heikkinen, P., Sherlock, V., Strong, K., Sussmann, R., and Warneke, T. (2014), Inferring regional sources and sinks of atmospheric $\mathrm{CO}_{2}$ from GOSAT XCO2 data, Atmos. Chem. Phys., 14, 3703-3727, doi:10.5194/acp-143703-2014.

Deutscher, N., J. Notholt, J. Messerschmidt, C. Weinzierl, T. Warneke, C. Petri, P. Grupe, K. Katrynski (2014), TCCON data from Bialystok, Poland, Release GGG2014R1. TCCON data archive, hosted by the Carbon Dioxide Information Analysis Center, Oak Ridge National Laboratory, Oak Ridge, Tennessee, U.S.A., http://dx.doi.org/10.14291/tccon.ggg2014.bialystok01.R1/1183984.

Detmers, R. G., O. Hasekamp, I. Aben, S. Houweling, T. T. van Leeuwen, A. Butz, J. Landgraf, P. Koehler, L. Guanter, and B. Poulter (2015), Anomalous carbon uptake in Australia as seen by GOSAT, Geophys. Res. Lett., 42, doi:10.1002/2015GL065161.

Dils, B., M. Buchwitz, M. Reuter, O. Schneising, H. Boesch, R. Parker, S. Guerlet, I. Aben, T. Blumenstock, J. P. Burrows, A. Butz, N. M. Deutscher, C. Frankenberg, F. Hase, O. P. Hasekamp, J. Heymann, M. De Maziere, J. Notholt, R. Sussmann, T. Warneke, D. Griffith, V. Sherlock, and D. Wunch (2014), The Greenhouse Gas Climate Change Initiative (GHG-CCI): comparative validation of GHG-CCI SCIAMACHY/ENVISAT and TANSO-FTS/GOSAT $\mathrm{CO}_{2}$ and $\mathrm{CH}_{4}$ retrieval algorithm products with measurements from the TCCON, Atmos. Meas. Tech., 7, 1723-1744.

Dils, B., et al. (2016), The GHG-CCI $\mathrm{XCO}_{2}$ and $\mathrm{XCH}_{4} \mathrm{CRDP} 3$ data set: Comparative validation of global satellite observations with measurements from the TCCON, this issue, manuscript in preparation. 
Dlugokencky, E. J., Bruhwiler, L., White, J. W. C., Emmons, L. K., Novelli, P. C., Montzka, S. A., Masarie, K. A., Lang, P. M., Crotwell, A. M., Miller, J. B., Gatti, L. V. (2009), Observational constraints on recent increases in the atmospheric $\mathrm{CH}_{4}$ burden, Geophys. Res. Lett., 36, L18803, doi:10.1029/2009GL039780.

Dlugokencky, E. and Tans, P. (2015), Trends in atmospheric carbon dioxide, National Oceanic \& Atmospheric Administration, Earth System Research Laboratory (NOAA/ESRL), available at: http://www.esrl.noaa.gov/gmd/ccgg/trends, last access: 7 October 2015.

Feng, L., P. I. Palmer, R. J. Parker, N. M. Deutscher, D. G. Feist, R. Kivi, I. Morino, and R. Sussmann (2016), Estimates of European uptake of $\mathrm{CO}_{2}$ inferred from GOSAT $\mathrm{XCO}_{2}$ retrievals: sensitivity to measurement bias inside and outside Europe, Atmos. Chem. Phys., 16, 12891302, doi:10.5194/acp-16-1289-2016.

Foucher, P. Y., Chédin, A., Dufour, G., Capelle, V., Boone, C. D., Bernath, P. (2009), Technical Note: Feasibility of $\mathrm{CO}_{2}$ profile retrieval from limb viewing solar occultation made by the ACE-FTS instrument, Atmos. Chem. Phys., 9, 2873-2890.

Frankenberg, C., Meirink, J. F., van Weele, M., Platt, U., Wagner, T. (2005), Assessing methane emissions from global spaceborne observations, Science, 308, 1010-1014.

Frankenberg, C., Aben, I., Bergamaschi, P., Dlugokencky, E. J., van Hees, R., Houweling, S., van der Meer, P., Snel, R., Tol, P. (2011), Global column-averaged methane mixing ratios from 2003 to 2009 as derived from SCIAMACHY: Trends and variability, J. Geophys. Res., doi:10.1029/2010JD014849.

Fraser, A., Palmer, P. I., Feng, L., et al. (2013), Estimating regional methane surface fluxes: the relative importance of surface and GOSAT mole fraction measurements, Atmos. Chem. Phys., 13, 5697-5713, doi:10.5194/acp-13-5697-2013.

Fraser, A., Palmer, P. I., Feng, L., et al. (2014), Estimating regional fluxes of $\mathrm{CO}_{2}$ and $\mathrm{CH}_{4}$ using space-borne observations of XCH4:XCO2, Atmos. Chem. Phys., 14, 12883-12895, www.atmos-chem-phys.net/14/12883/2014/, doi:10.5194/acp-14-12883-2014. 
GCOS (2011), Global Climate Observing System: SYSTEMATIC OBSERVATION REQUIREMENTS FOR SATELLITE-BASED DATA PRODUCTS FOR CLIMATE - 2011 Update - Supplemental details to the satellite-based component of the "Implementation Plan for the Global Observing System for Climate in Support of the UNFCCC (2010 Update)", GCOS-154.

Griffith, D. W. T., N. Deutscher, V. A. Velazco, P. O. Wennberg, Y. Yavin, G. Keppel Aleks, R. Washenfelder, G. C. Toon, J.-F. Blavier, C. Murphy, N. Jones, G. Kettlewell, B. Connor, R. Macatangay, C. Roehl, M. Ryczek, J. Glowacki, T. Culgan, G. Bryant (2014a), TCCON data from Darwin, Australia, Release GGG2014R0. TCCON data archive, hosted by the Carbon Dioxide Information Analysis Center, Oak Ridge National Laboratory, Oak Ridge, Tennessee, U.S.A., http://dx.doi.org/10.14291/tccon.ggg2014.darwin01.R0/1149290.

Griffith, D. W. T., V. A. Velazco, N. Deutscher, C. Murphy, N. Jones, S. Wilson, R. Macatangay, G. Kettlewell, R. R. Buchholz, M. Riggenbach (2014b), TCCON data from Wollongong, Australia, Release GGG2014R0. TCCON data archive, hosted by the Carbon Dioxide Information Analysis Center, Oak Ridge National Laboratory, Oak Ridge, Tennessee, U.S.A., http://dx.doi.org/10.14291/tccon.ggg2014.wollongong01.R0/1149291.

Guerlet, S., Basu, S., Butz, A., et al. (2013), Reduced carbon uptake during the 2010 Northern Hemisphere summer from GOSAT, Geophys. Res. Lett., doi: 10.1002/grl.50402.

Heymann, J., O. Schneising, M. Reuter, M. Buchwitz, V. V. Rozanov, V. A. Velazco, H. Bovensmann, and J. P. Burrows (2012a), SCIAMACHY WFM-DOAS $\mathrm{XCO}_{2}$ : comparison with CarbonTracker $\mathrm{XCO}_{2}$ focusing on aerosols and thin clouds, Atmos. Meas. Tech., 5, 19351952.

Heymann, J., H. Bovensmann, M. Buchwitz, J. P. Burrows, N. M. Deutscher, J. Notholt, M. Rettinger, M. Reuter, O. Schneising, R. Sussmann, and T. Warneke (2012b), SCIAMACHY WFMDOAS $\mathrm{XCO}_{2}$ : reduction of scattering related errors, Atmos. Meas. Tech., 5, 2375-2390. 
Heymann, J., M. Reuter, M. Hilker, M. Buchwitz, O. Schneising, H. Bovensmann, J. P. Burrows, A. Kuze, H. Suto, N. M. Deutscher, M. K. Dubey, D. W. T. Griffith, F. Hase, S. Kawakami, R. Kivi, I. Morino, C. Petri, C. Roehl, M. Schneider, V. Sherlock, R. Sussmann, V. A. Velazco, T. Warneke, and D. Wunch (2015), Consistent satellite $\mathrm{XCO}_{2}$ retrievals from SCIAMACHY and GOSAT using the BESD algorithm, Atmos. Meas. Tech., 8, 2961-2980.

Hollmann, R., Merchant, C. J., Saunders, R., et al. (2013), The ESA Climate Change Initiative: satellite data records for essential climate variables, Bulletin of the American Meteorological Society (BAMS), 0.1175/BAMS-D-11-00254.1.

Houweling, S., M. Krol, P. Bergamaschi et al. (2014), A multi-year methane inversion using SCIAMACHY, accounting for systematic errors using TCCON measurements, Atmos. Chem. Phys., 14, 3991-4012, http://www.atmos-chem-phys.net/14/3991/2014/, doi:10.5194/acp-143991-2014.

Houweling, S., D. Baker, S. Basu, H. Boesch, A. Butz, F. Chevallier, F. Deng, E. J. Dlugokencky, L. Feng, A. Ganshin, O. Hasekamp, D. Jones, S. Maksyutov, J. Marshall, T. Oda, C.W. O'Dell1, S. Oshchepkov, P. I. Palmer, P. Peylin, Z. Poussi, F. Reum, H. Takagi, Y. Yoshida, and R. Zhuravlev (2015), An intercomparison of inverse models for estimating sources and sinks of $\mathrm{CO}_{2}$ using GOSAT measurements, J. Geophys. Res. Atmos., 120, 5253-5266, doi:10.1002/2014JD022962.

IPCC (2013), Climate Change 2013: The Physical Science Basis, Working Group I Contribution to the Fifth Assessment Report of the Intergovernmental Report on Climate Change, http://www.ipcc.ch/report/ar5/wg1/, 2013.

Kaminski, T., W. Knorr, G. Schürmann, M. Scholze, P. J. Rayner, S. Zaehle, S. Blessing, W. Dorigo, V. Gayler, R. Giering, N. Gobron, J. P. Grant, M. Heimann, A. Hooker-Strout, S. Houweling, T. Kato, J. Kattge, D. Kelley, S. Kemp, E. N. Koffi, C. Köstler, P.P. Mathieu, B. Pinty, C. H. Reick, C. Rödenbeck, R. Schnur, K. Scipal, C. Sebald, T. Stacke, A. Terwisscha van Scheltinga, M. Vossbeck, H. Widmann, and T. Ziehn (2013), The BETHY/JSBACH Carbon 
Cycle Data Assimilation System: experiences and challenges. J. Geophys. Res., 118:doi:10.1002/jgrg.20118.

Kim, J., Kim, H. M., Cho, C.-H., Boo, K.-O., Jacobson, A. R., Sasakawa, M., Machida, T., Arshinov, M., and Fedoseev, N. (2016), Impact of Siberian observations on the optimization of surface $\mathrm{CO}_{2}$ flux, Atmos. Chem. Phys. Discuss., doi:10.5194/acp-2015-875, 2016.

Kirschke, S., Bousquet, P., Ciais, P., et al. (2013), Three decades of global methane sources and sinks, Nat. Geosci., 6, 813-823, doi:10.1038/ngeo1955.

Kort, E. A., C. Frankenberg, C. E. Miller, and T. Oda (2012), Space-based observations of megacity carbon dioxide, Geophys. Res. Lett., 39, L17806, doi:10.1029/2012GL052738.

Kort, E. A., Frankenberg, C., Costigan, K. R., et al. (2014), Four corners: The largest US methane anomaly viewed from space, Geophys. Res. Lett., 41, doi:10.1002/2014GL061503.

Kulawik, S., D. Wunch, C. O'Dell, C. Frankenberg, M. Reuter, T. Oda, F. Chevallier, V. Sherlock, M. Buchwitz, G. Osterman, C. E. Miller, P. O. Wennberg, D. Griffith, I. Morino, M. K. Dubey, N. M. Deutscher, J. Notholt, F. Hase, T. Warneke, R. Sussmann, J. Robinson, K. Strong, M. Schneider, M. De Mazière, K. Shiomi, D. G. Feist, L. T. Iraci, J. Wolf (2016), Consistent evaluation of ACOS-GOSAT, BESD-SCIAMACHY, CarbonTracker, and MACC through comparisons to TCCON, Atmos. Meas. Tech., 9, 683-709, doi:10.5194/amt-9-683-2016.

Kuze, A., Suto, H., Nakajima, M., and Hamazaki, T. (2009), Thermal and near infrared sensor for carbon observation Fourier-transform spectrometer on the Greenhouse Gases Observing Satellite for greenhouse gases monitoring, Appl. Opt., 48, 6716-6733.

Kuze, A., Taylor, T., Kataoka, F., Bruegge, C., Crisp, D., Harada, M., Helmlinger, M., Inoue, M., Kawakami, S., Kikuchi, N., Mitomi, Y., Murooka, J., Naitoh, M., O’Brien, D., O’Dell, C., Ohyama, H., Pollock, H., Schwandner, F., Shiomi, K., Suto, H., Takeda, T., Tanaka, T., Urabe, T., Yokota, T., and Yoshida, Y. (2014), Long-term vicarious calibration of GOSAT short-wave sensors: techniques for error reduction and new estimates of radiometric 
degradation factors, IEEE T. Geosci. Remote, 52, 3991-4004, doi:10.1109/TGRS.2013.2278696.

Laeng, A., J. Plieninger, T. von Clarmann, U. Grabowski, G. Stiller, E. Eckert, N. Glatthor, F. Haenel, S. Kellmann, M. Kiefer, A. Linden, S. Lossow, L. Deaver, A. Engel, M. Hervig, I. Levin, M. McHugh, S. Noël, G. Toon, and K. Walker, Validation of MIPAS IMK/IAA methane profiles, Atmos. Meas. Tech., 8, 5251-5261, 2015.

Le Quéré, C., Moriarty, R., Andrew, R. M., et al. (2015), Global carbon budget 2015, Earth Syst. Sci. Data, 7, 349-396, www.earth-syst-sci-data.net/7/349/2015/, doi:10.5194/essd-7-349-2015.

Lindqvist, H., C. W. O’Dell, S. Basu,3, H. Boesch, F. Chevallier, N. Deutscher, L. Feng, B. Fisher, F. Hase, M. Inoue, R. Kivi, I. Morino, P. I. Palmer, R. Parker, M. Schneider, R. Sussmann, and Y. Yoshida (2015), Does GOSAT capture the true seasonal cycle of $\mathrm{XCO}_{2}$ ?, Atmos. Chem. Phys., 15, 13023-13040, doi:10.5194/acp-15-13023-2015, 2015.

Maksyutov, S., H. Takagi, V. K. Valsala, M. Saito, T. Oda1, T. Saeki, D. A. Belikov, R. Saito, A. Ito, Y. Yoshida, I. Morino, O. Uchino, R. J. Andres, and T. Yokota (2013), Regional $\mathrm{CO}_{2}$ flux estimates for 2009-2010 based on GOSAT and ground-based $\mathrm{CO}_{2}$ observations, Atmos. Chem. Phys., 13, 9351-9373.

Masarie, K. A., Peters, W., Jacobson, A. R., and Tans, P. P. (2014), ObsPack: a framework for the preparation, delivery, and attribution of atmospheric greenhouse gas measurements, Earth Syst. Sci. Data, 6, 375-384, doi:10.5194/essd-6-375-2014.

Massart, S., A. Agustí-Panareda, J. Heymann, M. Buchwitz, F. Chevallier, M. Reuter, M. Hilker, J. P. Burrows, N. M. Deutscher, D. G. Feist, F. Hase, R. Sussmann, F. Desmet, M. K. Dubey, D. W. T. Griffith, R. Kivi, C. Petri, M. Schneider, V. A. Velazco (2016), Ability of the 4-D-Var analysis of the GOSAT BESD $\mathrm{XCO}_{2}$ retrievals to characterize atmospheric $\mathrm{CO}_{2}$ at large and synoptic scales, Atmos. Chem. Phys., 16, 1653-1671, doi:10.5194/acp-16-1653-2016.

Monteil, G., Houweling, S., Butz, A., et al. (2013), Comparison of $\mathrm{CH}_{4}$ inversions based on 15 months of GOSAT and SCIAMACHY observations, J. Geophy. Res., doi: 10.1002/2013JD019760, Vol 118, Issue 20, 11807-11823. 
Montero, J. M., Fernandez-Aviles, G., Mateu, J. (2015), Spatial and Spatio-Temporal Geostatistical Modeling and Kriging: John Wiley \& Sons Inc., (URL: http://www.ebook.de/de/product/20651121/jose_maria_ montero_gema_fernandez_aviles_jorge_mateu_spatial_and_spatio_ temporal_geostatistical_modeling_and_kriging.html).

Nisbet, E., Dlugokencky, E., Bousquet, P. (2014), Methane on the rise - again, Science, 343, 493-495, doi:10.1126/science.1247828.

Noël, S., Bramstedt, K., Rozanov, A., Bovensmann, H., Burrows, J. P. (2011), Stratospheric methane profiles from SCIAMACHY solar occultation measurements derived with onion peeling DOAS, Atmos. Meas. Tech., 4, 2567-2577.

Noël,S., K. Bramstedt, M. Hilker, P. Liebing, J. Plieninger, M. Reuter, A. Rozanov, H. Bovensmann, and J. P. Burrows (2016), Stratospheric $\mathrm{CH}_{4}$ and $\mathrm{CO}_{2}$ profiles derived from SCIAMACHY solar occultation measurements, Atmos. Meas. Tech., 9, 1485-1503, doi:10.5194/amt-9-14852016.

Notholt, J., Dils, B., Blumenstock, T., Brunner, D., Buchmann, B., De Mazière, M., et al. (2012). Product Validation and Algorithm Selection Report (PVASR) of the GHG-CCI project of ESA's Climate Change Initiative. Technical Report, link: http://www.esa-ghgcci.org/?q=webfm_send/314.

Notholt, J., C. Petri, T. Warneke, N. Deutscher, M. Buschmann, C. Weinzierl, R. Macatangay, P. Gruppe (2014), TCCON data from Bremen, Germany, Release GGG2014R0. TCCON data archive, hosted by the Carbon Dioxide Information Analysis Center, Oak Ridge National Laboratory, Oak Ridge, Tennessee, U.S.A., http://dx.doi.org/10.14291/tccon.ggg2014.bremen01.R0/1149275.

O’Dell, C. W., Connor, B., Boesch, H., et al. (2012), The $\mathrm{ACOS} \mathrm{CO}_{2}$ retrieval algorithm - Part 1: Description and validation against synthetic observations, Atmos. Meas. Tech., 5, 99-121. 
Oshchepkov, S., Bril, A., Maksyutov, S., Yokota, T. (2011), Detection of optical path in spectroscopic space-based observations of greenhouse gases: Application to GOSAT data processing, $J$. Geophys. Res., 116, D14304, doi:10.1029/2010JD015352.

Oshchepkov, S., Bril, A., Yokota, T., et al. (2013), Effects of atmospheric light scattering on spectroscopic observations of greenhouse gases from space. Part 2: Algorithm intercomparison in the GOSAT data processing for $\mathrm{CO}_{2}$ retrievals over TCCON sites, $J$. Geophys. Res., 118, 1493-1512, doi:10.1002/jgrd.50146.

Pandey, S., S. Houweling, M. Krol, I. Aben, F. Chevallier, E. J. Dlugokencky, L. V. Gatti, E. Gloor, J. B. Miller, R. Detmers, T. Machida, T. Roeckmann (2016), Inverse modeling of GOSATretrieved ratios of total column $\mathrm{CH}_{4}$ and $\mathrm{CO}_{2}$ for 2009 and 2010, Atmos. Chem. Phys., 16, 5043-5062, doi:10.5194/acp-16-5043-2016.

Parazoo, N. C., Bowman, K., Frankenberg, C., et al. (2013), Interpreting seasonal changes in the carbon balance of southern Amazonia using measurements of $\mathrm{XCO}_{2}$ and chlorophyll fluorescence from GOSAT, Geophys. Res. Lett., 40, 2829-2833, doi:10.1002/grl.50452.

Parker, R., Boesch, H., Cogan, A., Fraser, A., Feng, L, Palmer, P., Messerschmidt, J., Deutscher, N., Griffth, D., Notholt, J., Wennberg, P. Wunch, D. (2011), Methane Observations from the Greenhouse gases Observing SATellite: Comparison to ground-based TCCON data and Model Calculations, Geophys. Res. Lett., doi:10.1029/2011GL047871.

Parker, R. J., H. Boesch, K. Byckling, A. J. Webb, P. I. Palmer, L. Feng, P. Bergamaschi, F. Chevallier, J. Notholt, N. Deutscher, T. Warneke, F. Hase, R. Sussmann, S. Kawakami, R. Kivi, D. W. T. Griffith, and V. Velazco (2015), Assessing 5 years of GOSAT Proxy $\mathrm{XCH}_{4}$ data and associated uncertainties, Atmos. Meas. Tech., 8, 4785-4801, doi:10.5194/amt-8-47852015.

Peters, W., Jacobson, A. R., Sweeney, C., Andrews, A. E., Conway, T. J., Masarie, K., Miller, J. B., Bruhwiler, L. M. P., Petron, G., Hirsch, A. I., Worthy, D. E. J., van der Werf, G. R., Randerson, J. T., Wennberg, P. O., Krol, M. C., Tans, P. P. (2007): An atmospheric perspective on North American carbon dioxide exchange: CarbonTracker, Proceedings of the 

104(48), 18925-18930.

Peylin, P., Law, R. M., Gurney, et al. (2013), Global atmospheric carbon budget: results from an ensemble of atmospheric $\mathrm{CO}_{2}$ inversions, Biogeosciences, 10, 6699-6720, doi:10.5194/bg-106699-2013, URL http://www.biogeosciences.net/10/6699/2013/.

Reuter, M., Buchwitz, M., Schneising, O., Heymann, J., Bovensmann, H., Burrows, J. P. (2010), A method for improved SCIAMACHY $\mathrm{CO}_{2}$ retrieval in the presence of optically thin clouds, Atmos. Meas. Tech., 3, 209-232.

Reuter, M., Bovensmann, H., Buchwitz, M., Burrows, J. P., Connor, B. J., Deutscher, N. M., Griffith, D. W. T., Heymann, J., Keppel-Aleks, G., Messerschmidt, J., Notholt, J., Petri, C., Robinson, J., Schneising, O., Sherlock, V., Velazco, V., Warneke, T., Wennberg, P. O., Wunch, D. (2011), Retrieval of atmospheric $\mathrm{CO}_{2}$ with enhanced accuracy and precision from SCIAMACHY: Validation with FTS measurements and comparison with model results, $J$. Geophys. Res., 116, D04301, doi:10.1029/2010JD015047.

Reuter, M., H. Boesch, H. Bovensmann, A. Bril, M. Buchwitz, A. Butz, J. P. Burrows, C. W. O'Dell, S. Guerlet, O. Hasekamp, J. Heymann, N. Kikuchi, S. Oshchepkov, R. Parker, S. Pfeifer, O. Schneising, T. Yokota, and Y. Yoshida (2013), A joint effort to deliver satellite retrieved atmospheric $\mathrm{CO}_{2}$ concentrations for surface flux inversions: the ensemble median algorithm EMMA, Atmos. Chem. Phys., 13, 1771-1780.

Reuter, M., Buchwitz, M., Hilker, M., et al. (2014a), Satellite-inferred European carbon sink larger than expected, Atmos. Chem. Phys., 14, 13739-13753, www.atmos-chemphys.net/14/13739/2014/, doi:10.5194/acp-14-13739-2014.

Reuter, M., Buchwitz, M., Hilboll, A., et al. (2014b), Decreasing emissions of NOx relative to $\mathrm{CO}_{2}$ in East Asia inferred from satellite observations, Nature Geoscience, 28 Sept. 2014, doi:10.1038/ngeo2257, pp.4.

Reuter, M., Hilker, M., Schneising, O., Buchwitz, M., Heymann (2016), J., ESA Climate Change Initiative (CCI) Comprehensive Error Characterisation Report: BESD full-physics retrieval 
algorithm for $\mathrm{XCO}_{2}$ for the Essential Climate Variable (ECV) Greenhouse Gases (GHG), Version 2.0, revision 1, 10.02.2016 (pdf file: http://www.esa-ghg-cci.org/webfm_send/284).

Rigby, M., Prinn, R. G., Fraser, P. J., Simmonds, P. G., Langenfelds, R. L., Huang, J., Cunnold, D. M., Steele, L. P., Krummel, P. B., Weiss, R. F., O’Doherty, S., Salameh, P. K., Wang, H. J., Harth, C. M., Mühle, J., Porter, L. W. (2008), Renewed growth of atmospheric methane, Geophys. Res. Lett., 35, L22805, doi:10.1029/2008GL036037.

Rodgers, C. D. (2000), Inverse Methods for Atmospheric Sounding: Theory and Practice, World Scientific Publishing.

Ross, A. N., Wooster, M. J., Boesch, H., Parker, R. (2013), First satellite measurements of carbon dioxide and methane emission ratios in wildfire plumes, Geophys. Res. Lett., 40, 1-5, doi:10.1002/grl.50733.

Saeki, T., Maksyutov, S., Saito, M., Valsala, V., Oda, T., Andres, R. J., Belikov, D., Tans, P., Dlugokencky, E., Yoshida, Y., Morino, I., Uchino, O., and Yokota, T. (2013), Inverse modeling of $\mathrm{CO}_{2}$ fluxes using GOSAT data and multi-year ground-based observations, Sci. Online Lett. Atmos., 9, 45-50, doi:10.2151/sola.2013-011.

Schaefer, H., S. E. Mikaloff Fletcher, C. Veidt, K. R. Lassey, G. W. Brailsford, T. M. Bromley, E. J. Dlugokencky, S. E. Michel, J. B. Miller, I. Levin, D. C. Lowe, R. J. Martin, B. H. Vaughn, J. W. C. White (2016), A 21st-century shift from fossil-fuel to biogenic methane emissions indicated by ${ }^{13} \mathrm{CH}_{4}$, Science, Vol. 352, Issue 6281, pp. 80-84, doi 10.1126/science.aad2705.

Schepers, D., Guerlet, S., Butz, A., Landgraf, J., Frankenberg, C., Hasekamp, O., Blavier, J.-F., Deutscher, N. M., Griffith, D. W. T., Hase, F., Kyro, E., Morino, I., Sherlock, V., Sussmann, R., Aben, I. (2012), Methane retrievals from Greenhouse Gases Observing Satellite (GOSAT) shortwave infrared measurements: Performance comparison of proxy and physics retrieval algorithms, J. Geophys. Res., 117, D10307, doi:10.1029/2012JD017549.

Schneising, O., Buchwitz, M., Burrows, J. P., Bovensmann, H., Reuter, M., Notholt, J., Macatangay, R., Warneke, T. (2008), Three years of greenhouse gas column-averaged dry air mole fractions retrieved from satellite - Part 1: Carbon dioxide, Atmos. Chem. Phys., 8, 3827-3853. 
Schneising, O., Buchwitz, M., Burrows, J. P., Bovensmann, H., Bergamaschi, P., Peters, W. (2009), Three years of greenhouse gas column-averaged dry air mole fractions retrieved from satellite - Part 2: Methane, Atmos. Chem. Phys., 9, 443-465.

Schneising, O., Buchwitz, M., Reuter, M., Heymann, J., Bovensmann, H., and Burrows, J. P. (2011), Long-term analysis of carbon dioxide and methane column-averaged mole fractions retrieved from SCIAMACHY, Atmos. Chem. Phys., 11, 2881-2892.

Schneising, O., Bergamaschi, P., Bovensmann, H., Buchwitz, M., Burrows, J. P., Deutscher, N. M., Griffith, D. W. T., Heymann, J., Macatangay, R., Messerschmidt, J., Notholt, J., Rettinger, M., Reuter, M., Sussmann, R., Velazco, V. A., Warneke, T., Wennberg, P. O., Wunch, D. (2012), Atmospheric greenhouse gases retrieved from SCIAMACHY: comparison to ground-based FTS measurements and model results, Atmos. Chem. Phys., 12, 1527-1540.

Schneising, O., Heymann, J., Buchwitz, M., Reuter, M., Bovensmann, H., and Burrows, J. P. (2013), Anthropogenic carbon dioxide source areas observed from space: assessment of regional enhancements and trends, Atmos. Chem. Phys., 13, 2445-2454.

Schneising, O., Reuter, M., Buchwitz, M., Heymann, J., Bovensmann, H., and Burrows, J. P. (2014a), Terrestrial carbon sink observed from space: variation of growth rates and seasonal cycle amplitudes in response to interannual surface temperature variability, Atmos. Chem. Phys., 14, $133-141$.

Schneising, O., Burrows, J. P.,, Dickerson, R. R., Buchwitz, M., Reuter, M., Bovensmann, H. (2014b), Remote sensing of fugitive methane emissions from oil and gas production in North American tight geologic formations, Earth's Future, 2, DOI: 10.1002/2014EF000265, pp. 11.

Schulze, E. D., Luyssaert, S., Ciais, P, et al. (2009), Importance of methane and nitrous oxide emissions for Europe's terrestrial greenhouse gas balance, Nat. Geosci., 2, 842-850, doi:10.1038/ngeo686.

Shindell, D. T., Pechony, O., Voulgarakis, A., et al. (2013), Interactive ozone and methane chemistry in GISS-E2 historical and future climate simulations, Atmos. Chem. Phys., 13, 2653-2689, doi:10.5194/acp-13-2653-2013. 
Stephens, B. B., Gurney, K. R., Tans, P. P., Sweeney, C., Peters, W., Bruhwiler, L., Ciais, P., Ramonet, M., Bousquet, P., Nakazawa, T., Aoki, S., Machida, T., Inoue, G., Vinnichenko, N., Lloyd, J., Jordan, A., Heimann, M., Shibistova, O., Langenfelds, R. L., Steele, L. P., Francey, R. J., Denning, A. S. (2007), Weak northern and strong tropical land carbon uptake from vertical profiles of atmospheric CO2, Science, 22, 1732-1735.

Sussmann, R., Forster, F., Rettinger, M., and Bousquet, P. (2012), Renewed methane increase for five years (2007-2011) observed by solar FTIR spectrometry, Atmos. Chem. Phys., 12, 4885-4891.

Takagi, H., S. Houweling, R. J. Andres, D. Belikov, A. Bril, H. Boesch, A. Butz, S. Guerlet, O. Hasekamp, S. Maksyutov, I. Morino1, T. Oda, C. W. O'Dell, S. Oshchepkov, R. Parker, M. Saito, O. Uchino, T. Yokota, Y. Yoshida, V. Valsala (2014), Influence of differences in current GOSAT XCO 2 retrievals on surface flux estimation, Geophys. Res. Lett., 41, 25982605, doi:10.1002/2013GL059174.

Turner, A. J., D. J. Jacob, K. J. Wecht, J. D. Maasakkers, S. C. Biraud, H. Boesch, K. W. Bowman, N. M. Deutscher, M. K. Dubey, D. W. T. Griffith, F. Hase, A. Kuze, J. Notholt, H. Ohyama, R. Parker, V. H. Payne, R. Sussmann, V. A. Velazco, T. Warneke, P. O. Wennberg, and D. Wunch (2015), Estimating global and North American methane emissions with high spatial resolution using GOSAT satellite data, Atmos. Chem. Phys., 15, 7049-7069, doi:10.5194/acp15-7049-2015.

Turner, A. J., D. J. Jacob, J. Benmergui, S. C. Wofsy, J. D. Maasakkers, A. Butz, O. Hasekamp, and S. C. Biraud (2016), A large increase in U.S. methane emissions over the past decade inferred from satellite data and surface observations, Geophys. Res. Lett., 43, 2218-2224, doi:10.1002/2016GL067987.

Veefkind, J. P., Aben, I., McMullan, K., Förster, H., De Vries, J., Otter, G., Claas, J., Eskes, H. J., De Haan, J. F., Kleipool, Q., Van Weele, M., Hasekamp, O., Hoogeveen, R., Landgraf, J., Snel, R., Tol, P.,Ingmann, P., Voors, R., Kruizinga, B., Vink, R., Visser, H., and Levelt, P. F. (2012), TROPOMI on the ESA Sentinel-5 Precursor: A GMES mission for global 
observations of the atmospheric composition for climate, air quality and ozone layer applications. Rem. Sens. Environment, 120:70-83.

Velazco, V. A., M. Buchwitz, H. Bovensmann, M. Reuter, O. Schneising, J. Heymann, T. Krings, K.

Wennberg, P. O., D. Wunch, C. Roehl, J.-F. Blavier, G. C. Toon, N. Allen, P. Dowell, K. Teske, C. Martin, J. Martin (2014b), TCCON data from Lamont, Oklahoma, USA, Release GGG2014R0. TCCON data archive, hosted by the Carbon Dioxide Information Analysis Center, Oak Ridge National Laboratory, Oak Ridge, Tennessee, U.S.A., http://dx.doi.org/10.14291/tccon.ggg2014.lamont01.R0/1149159.

Worden, J. R., A. J. Turner, A. Bloom, S. S. Kulawik, J. Liu, M. Lee, R. Weidner, K. Bowman, C. Frankenberg, R. Parker, and V. H. Payne (2015), Quantifying lower tropospheric methane concentrations using GOSAT near-IR and TES thermal IR measurements, doi:10.5194/amt-83433-2015, Atmos. Meas. Tech., 8, 3433-3445.

Wunch, D., Toon, G. C., Wennberg, P. O., Wofsy, S. C., Stephens, B. B., Fischer, M. L., Uchino, O., Abshire, J. B., Bernath, P., Biraud, S. C., Blavier, J.-F. L., Boone, C., Bowman, K. P., Browell, E. V., Campos, T., Connor, B. J., Daube, B. C., Deutscher, N. M., Diao, M., Elkins, 
J. W., Gerbig, C., Gottlieb, E., Griffith, D. W. T., Hurst, D. F., Jimenez, R., Keppel-Aleks, G.,

Kort, E. A., Macatangay, R., Machida, T., Matsueda, H., Moore, F., Morino, I., Park, S., Robinson, J., Roehl, C. M., Sawa, Y., Sherlock, V., Sweeney, C., Tanaka, T., Zondlo, M. A. (2010), Calibration of the Total Carbon Column Observing Network using aircraft profile data, Atmos. Meas. Tech., 3, 1351-1362, doi:10.5194/amt-3-1351-2010, http://www.atmos-

Wunch, D., Toon, G. C., Blavier, J.-F. L., Washenfelder, R. A., Notholt, J., Connor, B. J., Griffith, D. W. T., Sherlock, V., Wennberg, P. O. (2011a), The Total Carbon Column Observing Network,

Wunch, D., Wennberg, P. O., Toon, G. C., et al. (2011b), A method for evaluating bias in global measurements of $\mathrm{CO}_{2}$ total columns from space, Atmos. Chem. Phys., 11, 12317-12337,

Wunch, D., Toon, G. C., Sherlock, V., Deutscher, N. M, Liu, X., Feist, D. G., and Wennberg, P. O. (2015), The Total Carbon Column Observing Network’s GGG2014 Data Version. Carbon Dioxide Information Analysis Center, Oak Ridge National Laboratory, Oak Ridge, Tennessee,

Yoshida, Y., Kikuchi, N., Morino, I., et al. (2013), Improvement of the retrieval algorithm for GOSAT

Zhang, Q., R.-L. Shia, S. P. Sander, and Y. L. Yung (2016), $\mathrm{XCO}_{2}$ retrieval error over deserts near SWIR $\mathrm{XCO}_{2}$ and $\mathrm{XCH}_{4}$ and their validation using TCCON data, Atmos. Meas. Tech., 6, 15331547, doi:10.5194/amt-6-1533-2013. 